\title{
Comparative Characterization and Autoradiographic Distribution of Neuropeptide Y Receptor Subtypes in the Rat Brain
}

\author{
Yvan Dumont, ${ }^{1}$ Alain Fournier, ${ }^{2}$ Serge St-Pierre, ${ }^{2}$ and Rémi Quirion ${ }^{1}$ \\ 'Douglas Hospital Research Center and Department of Psychiatry, Faculty of Medicine, McGill University, Montréal, \\ Québec, Canada H4H 1R3 and ${ }^{2}$ NRS-Santé, Pointe-Claire, Québec, Canada H3R 1 G6
}

\begin{abstract}
Some evidence has suggested the existence and differential distribution of neuropeptide $Y$ (NPY) receptor subtypes in the mammalian brain (Dumont et al., 1990; Aicher et al., 1991). We now report on the extensive characterization and visualization of at least two classes of NPY receptor sites using a highly selective $Y_{1}$ analog, $\left[\right.$ Leu $\left.^{31}, P^{2}{ }^{34}\right]-N P Y$ or $\left[P^{20}{ }^{34}\right]-$ NPY, and a relatively specific $Y_{2}$ competitor, NPY ${ }_{13-36}$. Autoradiographic studies using ${ }^{125}$-peptide $Y Y$ (125|-PYY) clearly reveal that the $Y$, receptor subtype is most abundant in various cortical areas, the dentate gyrus of the hippocampal formation, the claustrum, and the reuniens nucleus of the thalamus. In most other regions, ${ }^{125}$-PYY binding is potently inhibited by increasing concentrations of either NPY ${ }_{2-36}$ or NPY ${ }_{13-36}$, suggesting a $Y_{2}$-like profile. Furthermore, binding assays using homogenates from discrete brain regions clearly demonstrate that various NPY fragments and analogs compete for ${ }^{125}$-PYY labeling with profiles indicative of heterogeneity of NPY receptor subtypes, even in the presence of a selective $Y_{1}$ blocker. Thus, it is likely that, in addition to the $Y_{1}$ receptor, which is particularly concentrated in cortical areas, the rat brain is enriched with a receptor class $\left(Y_{2}\right)$ that can exist under high- or low-affinity states or with additional receptor subtypes that are recognized by ${ }^{125} \mid-P Y Y$. These findings cannot be explained by the existence of the very recently reported $Y_{3}$ receptor subtype, since $P Y Y$ does not possess significant affinity to this site (Grundemar et al., 1991). Further experiments are currently in progress to determine the nature and functional significance of each of these NPY/PYY receptor sites.
\end{abstract}

[Key words: neuropeptide $Y$, peptide $Y Y$, receptor subtypes, autoradiography, distribution, rat brain]

Neuropeptide Y (NPY), a 36 amino acid polypeptide isolated from porcine brain, shares important sequence homology with peptide YY (PYY) and various pancreatic polypeptides (PP) (Tatemoto, 1982; Tatemoto et al., 1982). Therefore, it has been included as a member of the PP family (Tatemoto, 1982; Tatemoto et al., 1982; Emson and DeQuidt, 1984). Interestingly, NPY is one of the most abundant peptides found in the CNS

\footnotetext{
Received Mar. 31, 1992; revised June 18, 1992; accepted July 10. 1992.

A.F. and R.Q. are Chercheur-Boursiers of the Fonds de la Recherche en Santé du Québec. This work was supported by the Medical Research Council of Canada (Program Grant 38 ) and a fellowship from Eli Lilly Co.

Correspondence and reprint requests should be addressed to Dr. Rémi Quirion, Douglas Hospital Research Center, 6875 Boulevard LaSalle, Verdun, Québec, Canada $\mathrm{H} 4 \mathrm{H} 1 \mathrm{R}$ ?

Copyright (C) 1993 Society for Neuroscience $0270-6474 / 93 / 130073-14 \$ 05.00 / 0$
}

(Chronwall et al., 1985; O’Donohue et al., 1985; DeQuidt and Emson, 1986a,b). NPY-like immunoreactivity is especially concentrated in various regions of the limbic system including certain cortical areas, the hippocampal formation, the amygdaloid nuclei, and the hypothalamus (Chronwall et al., 1985; O'Donohue et al., 1985; DeQuidt and Emson, 1986a,b). Moreover, in situ hybridization studies have revealed that the distribution of NPY mRNA correlates rather well with that of NPY-likeimmunoreactive material (Terenghi et al., 1987; Chan-Palay et al., 1988).

Many studies have demonstrated the existence of specific receptors for NPY and related peptides in mammalian brain (Chang et al., 1985, 1986, 1988; Saria et al., 1985; Martel et al., 1986, 1987, 1988, 1990a,b; Inui et al., 1988, 1989; Walker and Miller, 1988; Busch-Sorensen et al., 1989; Lynch et al., 1989; Sheikh et al., 1989a,b; Ohkubo et al., 1990; Quirion et al., 1990; Rosier et al., 1990; Sheikh and Williams, 1990; Dumont et al., 1992; Quirion and Martel, 1992). Using anatomical methods, it was shown that NPY binding sites are concentrated mostly in the hippocampal formation, various cortical areas, the olfactory bulb, and the lateral septum. Lower but still highly significant densities of NPY sites are also present in the striatum, in various thalamic, hypothalamic, and brainstem nuclei, and in the cerebellum (Martel et al., 1986, 1987, 1988, 1990a; Inui et al., 1989; Lynch et al., 1989; Ohkubo et al., 1990; Quirion et al., 1990; Rosier et al., 1990). The overall anatomical distribution observed using a variety of radioligands including ${ }^{3} \mathrm{H}-\mathrm{NPY},{ }^{125} \mathrm{I}-$ Bolton-Hunter-NPY, or ${ }^{125} \mathrm{I}-\mathrm{PYY}$ is similar. However, some differences were detected in certain hypothalamic and brainstem nuclei as well as in the cerebellum (Lynch et al., 1989; Martel et al., 1990a; Quirion et al., 1990), suggesting the possible heterogeneity of NPY receptors in the mammalian brain.

This concept is also supported by functional studies. As early as 1986, Wahlestedt and coworkers suggested the existence of two classes of NPY receptors $\left(Y_{1}\right.$ and $\left.Y_{2}\right)$ in peripheral tissues. They observed that while the full NPY/PYY sequence was required to act upon the $Y$, receptor, $C$-terminal fragments such as NPY ${ }_{13-36}$ and PYY ${ }_{13-36}$ were able to activate the $Y_{2}$ subtype fully, albeit with lower potencies than the native peptides (Wahlestedt et al., 1986). In the CNS, NPY acts to stimulate food and water intake, probably via $Y$, receptors since various $C$-terminal fragments were inactive in this paradigm (Danho et al., 1988; Flood and Morley, 1989; Jolicoeur et al., 199 la,b; Leibowitz and Alexander, 1991). In contrast, the facilitation of memory retention induced by NPY is most likely related to the activation of $Y_{2}$ receptors (Flood and Morley, 1989). The effects of these peptides on locomotor behaviors and various cardio- 
vascular parameters are either inhibitory or stimulatory depending upon the activation of one of these two receptor types (Heilig and Murison, 1987; Heilig et al., 1988; Aguirre et al., 1990). There is a possibility that these two receptor classes are coupled to different transduction mechanisms, the $Y$, sites being coupled to phosphoinositol turnover(Wahlestedt, 1987; Hinson et al., 1988; Widdowson and Halaris, 1990a) and the $Y_{2}$ receptor bcing linked to the activity of adenylate cyclase (Härfstrand et al., 1987; Petrenko et al., 1987; Wahlestedt, 1987; WestlindDanielsson et al., 1987, 1988; Widdowson and Halaris, 1990b). More recently, the existence of yet another receptor class $\left(\mathrm{Y}_{3}\right)$ was proposed on the basis that certain effects induced by NPY are shared by both $\mathrm{Y}_{1}$ and $\mathrm{Y}_{2}$ agonists but not by the homolog PYY (Grundemar et al., 1991; Wahlestedt et al., 1992). Rimland et al. (1991) have just reported the cloning of a G-proteincoupled receptor that could represent that new NPY receptor class, although this remains to be fully established.

In a previous study, we provided preliminary evidence for the differential distribution of $Y_{1}$ and $Y_{2}$ receptors in the rat brain (Dumont et al., 1990), based on the differential competition profile of ${ }^{125} \mathrm{I}-\mathrm{PYY}$ binding sites by selective $\mathrm{Y}_{1}$ agonists such as [Leu ${ }^{31}$, Pro $\left.^{34}\right]-N P Y$ and $\left[\right.$ Pro $\left.^{34}\right]-N P Y$ (Fuhlendorff et al., 1990a,b; Schwartz et al., 1990) and $Y_{2}$-preferential fragments. However, the precise proportion of cach receptor subtype in a given brain region was not established. Moreover, it is still unclear if these two broad classes of NPY receptors constitute a homogeneous population of sites or if they include other putative subtypes.

Consequently, the aim of the present study was to investigate, in detail, the respective autoradiographic distribution of $Y_{1}$ and $Y_{2}$ receptors in the rat brain. Competition binding profiles using various selective NPY-related peptides clearly suggest further heterogeneity of NPY receptors in the rat brain.

\section{Materials and Methods}

Materials. Male Sprague-Dawley CD rats (200-250 gm) obtained from Charles River Canada (St-Constant, Québec, Canada) were maintained on a $12 \mathrm{hr}$ light-dark cycle (light on at 7:00 AM) in temperature- and humidity-controlled rooms. Animals were fed standard laboratory chow and had access to tap water ad libidum. Animal care was according to protocols and guidelines approved by McGill University and the Canadian Council for Animal Care.

Analogs and fragments of porcine NPY (pNPY) were synthesized in our laboratories as previously described (Forest et al., 1990; Martel et al., 1990b). ${ }^{125} \mathrm{I}-\mathrm{PYY}(2200 \mathrm{Ci} / \mathrm{mmol})$ was obtained from New England Nuclear-DuPont (Boston, MA), and film (Hyperfilm) and ${ }^{125}$ I standards were purchased from Amersham Canada Ltd. (Oakville, Ontario, Canada). All other chemicals were of analytical grade and were obtained from Fisher Scientific Co. (Montréal, Québec, Canada) or Sigma Chemical Co. (St. Louis, MO).

Receptor autoradiography. Receptor autoradiography was performed as recently described by our group (Martel et al., 1990a). Briefly, rats were killed by decapitation, and their brains were rapidly removed from the skull, frozen in 2-methylbutane at $-40^{\circ} \mathrm{C}$ for $15 \mathrm{sec}$, and then kept at $-80^{\circ} \mathrm{C}$ until needed. Sections $(20 \mu \mathrm{m})$ were obtained using a Bright cryomicrotome at $-17^{\circ} \mathrm{C}$ before being mounted on gelatin-chromealum-coated slides, dried overnight in a desiccator at $4^{\circ} \mathrm{C}$, and then kept at $-80^{\circ} \mathrm{C}$ until use.

On the day of the experiments, adjacent coronal brain sections were preincubated for $60 \mathrm{~min}$ at room temperature in a Krebs-Ringer phosphate buffer (KRP) at pH 7.4 and then incubated for $120 \mathrm{~min}$ in a fresh preparation of KRP buffer supplemented with $0.1 \%(\mathrm{w} / \mathrm{v})$ bovine serum albumin, $0.05 \%(\mathrm{w} / \mathrm{v})$ bacitracin, and $25 \mathrm{pM}{ }^{125} \mathrm{I}-\mathrm{PYY}$ in the presence or absence of either $\mathrm{NPY}_{2-36}, \mathrm{NPY}_{13-36}$, or [Pro $\left.{ }^{34}\right]-\mathrm{NPY}$ at concentrations ranging from $10^{-9}$ to $10^{-6} \mathrm{M}$. Nonspecific binding was determined using adjacent sections incubated in the presence of $1 \mu \mathrm{M}$ unlabeled porcine NPY (pNPY). At the end of the incubation period, sections were washed four times (4 min each) in ice-cold buffer, dipped in deionized water to remove salts, and rapidly dried under a stream of cold air. Sections were then placed in $\mathrm{x}$-ray cassettes and apposed against Hyperfilm for $6 \mathrm{~d}$. Films were developed and analyzed using the standard procedure described by Martel et al. (1990a).

Membrane binding assays. Membrane binding assays were performed as previously described (Martel et al., 1986, 1990b). Briefly, rats were killed by decapitation and their brains rapidly removed; the olfactory bulb, frontoparietal cortex, striatum (including the lateral septum), hippocampus, and cerebellum were rapidly dissected on ice and then homogenized in KRP buffer using a Brinkman polytron (at setting 6 for $15-20 \mathrm{sec}$ ) and centrifuged at $49,000 \times g$ for $15 \mathrm{~min}$. Supernatants were discarded and pellets washed, resuspended, and recentrifuged. Final pellets from the olfactory bulb, the frontoparietal cortex, and the hippocampus obtained from four animals and from the striatum and the cerebellum from eight rats were rinsed and resuspended in $50 \mathrm{ml}$ of KRP buffer each.

Binding assays were initiated by adding $100 \mu \mathrm{l}$ of membrane preparations in a final volume of $500 \mu \mathrm{l}$ of KRP buffer containing $0.1 \%$ bovine serum albumin, $0.05 \%$ bacitracin, $20-25$ pM ${ }^{125}$ I-PYY, and various competitors (pNPY, PYY, NPY ${ }_{2-36}, \mathrm{NPY}_{13-36}$, or $\left[\mathrm{Leu}^{31}\right.$, Pro $\left.^{34}\right]-\mathrm{NPY}$ ) at concentrations varying from $10^{-12}$ to $10^{-6} \mathrm{M}$. Following a $2 \mathrm{hr}$ incubation period at $25^{\circ} \mathrm{C}$, the reaction was terminated by rapid filtration through Schleicher and Schull \#32 filters (previously soaked in $1.0 \%$ polyethyleneimine) using a cell harvester filtering apparatus (Brandel Instruments, Gaithersburg, MD). Filters were rinsed three times with $3 \mathrm{ml}$ of cold KRP buffer and dried, and the radioactivity remaining on filters was quantified using a gamma counter (LKB Instruments) with $70 \%$ efficiency. The percentage of specifically bound ${ }^{125}$ I-PYY was determined as the difference in binding observed in the presence and absence of $1 \mu \mathrm{m}$ unlabeled pNPY and represented between $80 \%$ and $90 \%$ of total binding.

Binding data were analyzed using the LUNDON SOFTWARE competition program. Individual competition binding curves were fitted to both a one- and a two-binding-site model. If the $p$ value was less than 0.05 on the Fisher test, a two-site model was accepted as representing the best fit for the data. All values are expressed as percentage of specific binding and represented as the mean \pm SEM of four to eight individual experiments determinations, with each point done in triplicate.

\section{Results}

Comparative autoradiographic distribution of NPY receptor subtypes

As reported earlier (Lynch et al., 1989; Martel et al., 1990a), the total population of ${ }^{25} \mathrm{I}-\mathrm{PYY}$ receptor binding sites is widely but discretely distributed in the rat brain (Figs. 1-4). Autoradiographic data obtained at the level of the olfactory bulb (Fig. 1), striatum (Fig. 2), hippocampal formation (Fig. 3), and cerebellum (Fig. 4) show that ${ }^{125}$ I-PYY bound with high specificity to NPY/PYY receptor sites as indicated by the absence of labeling in the presence of a saturating concentration of pNPY. High levels of specific ${ }^{125}$ I-PYY binding are present in all parts of the anterior olfactory nuclei (Fig. 1, Table 1), the superficial layers of the cortex (Figs. 1-3, Table 1), the lateral septum (Fig. 2, Table 1), the piriform cortex, and the oricns layer and stratum radiatum of the hippocampus (Fig. 3, Table 1). Areas such as the striatum (Fig. 2, Table 1), the cerebellum (Fig. 4, Table 1), and most brainstem nuclei (Fig. 4, Table 1) contained relatively moderate to low amounts of ${ }^{125} \mathrm{I}-\mathrm{PYY}$ binding.

The fragment $\mathrm{NPY}_{2-36}$ inhibited, in a concentration-dependent manner, ${ }^{125}$ I-PYY binding without obvious specificity for a given brain region or nucleus (Figs. 1-4). At a concentration of $10^{-6} \mathrm{M}, \mathrm{NPY}_{2-36}$ fully competed for ${ }^{125}$ I-PYY binding sites in all areas including the cingulum, frontal, and orbital cortices and the anterior olfactory nuclei (Fig. 1); the frontoparietal cortex, claustrum, striatum, and lateral septum (Fig. 2); the hippocampus, piriform cortex, and various thalamic and hypothalamic nuclei (Fig. 3); as well as the cerebellum and various brainstem nuclei (Fig. 4).

In contrast, the specific $Y_{1}$ agonist [Pro $\left.{ }^{34}\right]-N P Y$ and the $Y_{2}$ fragment NPY ${ }_{13-36}$ showed different competition profiles in var- 
$N P Y_{2-36}$
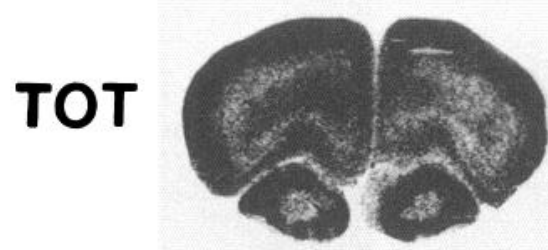

$-9$

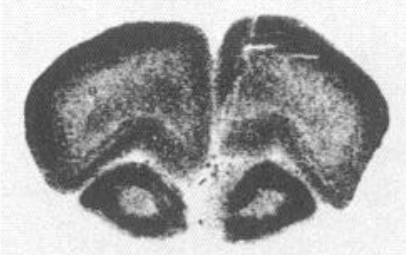

$-8$

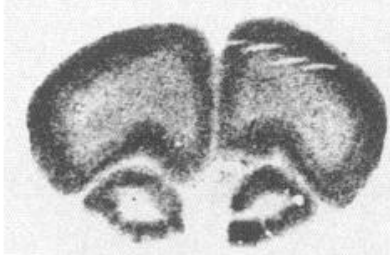

$-7$

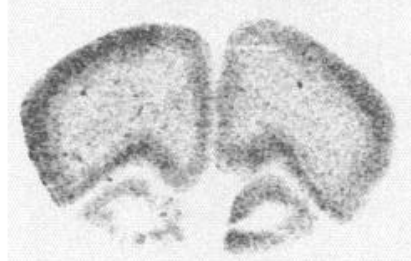

$-6$

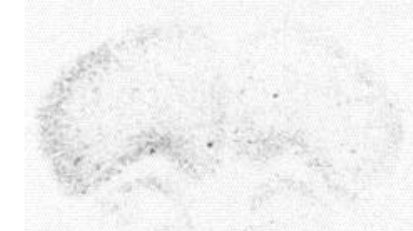

NS
NPY $13-36$
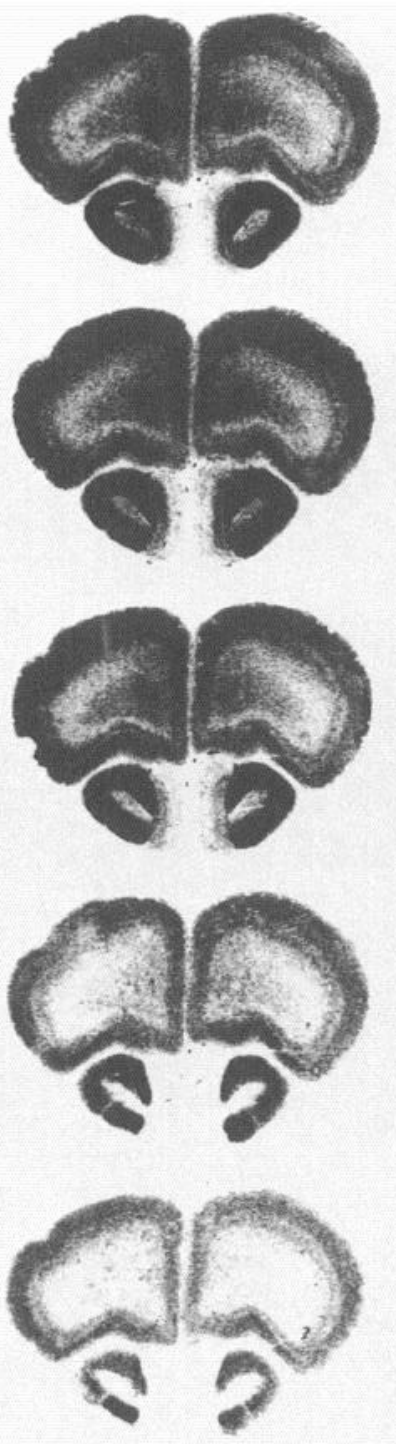

$\left[\right.$ Pro $\left.^{34}\right]-$ NPY
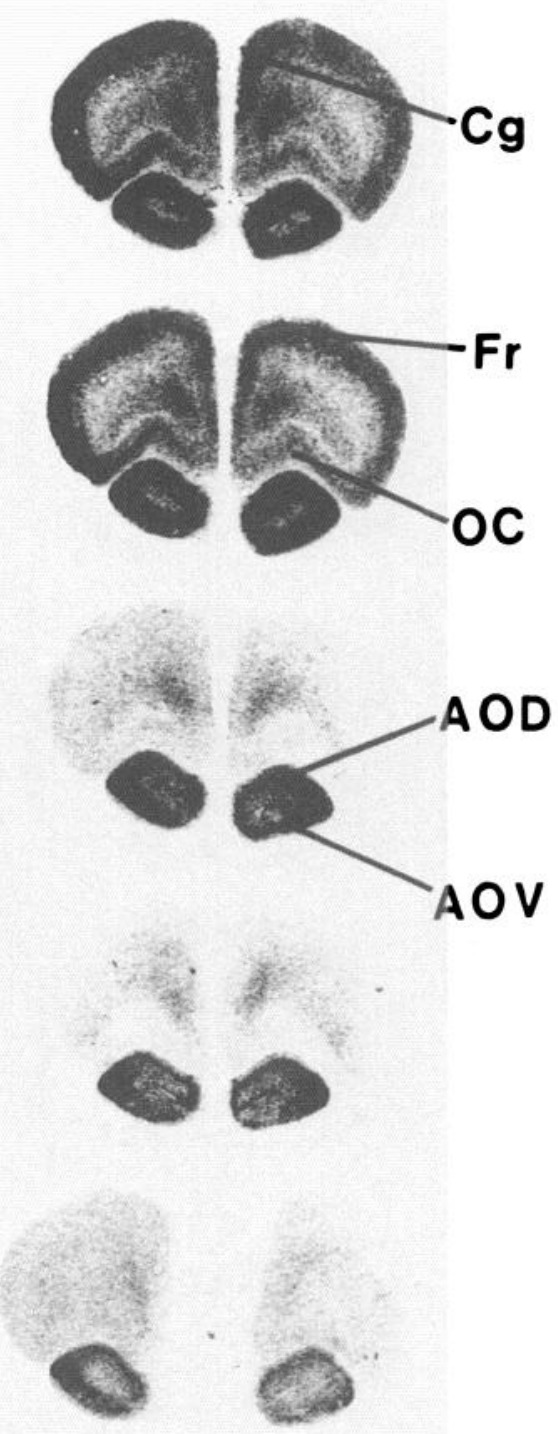
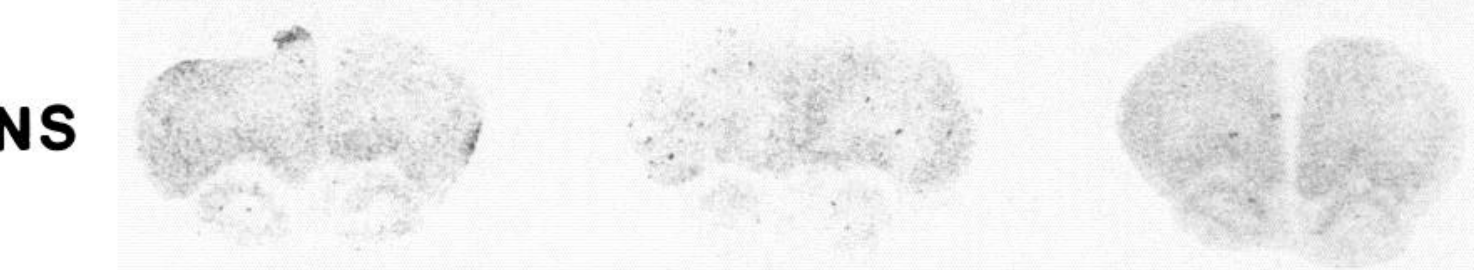

Figure 1. Photomicrographs of the autoradiographic distribution of ${ }^{125}$ I-PYY binding sites at the level of the frontal cortex of the rat brain. Adjacent coronal sections were incubated with ${ }^{125} \mathrm{I}-\mathrm{PYY}$ alone (20-25 pM) (TOT) or in the presence of either $1 \mu \mathrm{M}$ pNPY (nonspecific binding, $N S$ ) or increasing concentrations (molar) of competitors such as NPY ${ }_{2.36}, \mathrm{NPY}_{13-36}$, or [Pro ${ }^{34}$ ]-NPY. Note that cortical labeling is highly sensitive to [Pro $\left.{ }^{34}\right]$-NPY but not to NPY ${ }_{13-36}$. $A O D$, anterior olfactory nucleus, dorsal part; $A O V$, anterior olfactory nucleus, ventral part; $C g$, cingulate cortex; $\mathrm{Fr}$, frontal cortex; $O C$, orbital cortex.

ious brain regions. In the frontal cortex, the labeling of ${ }^{125} I-P Y Y$ is almost completely inhibited by a low (10 nM) concentration of [Pro $\left.{ }^{34}\right]-\mathrm{NPY}$, whereas $\mathrm{NPY}_{13-36}$ is only weakly active in this area, even at micromolar concentrations (Fig. 1, Table 1). This suggests that the frontal cortex is especially enriched with the
$\mathrm{Y}_{1}$ receptor subtype. Interestingly, neither $\mathrm{NPY}_{13-36}$ nor [Pro $\left.{ }^{34}\right]-$ NPY acted as potent competitors in the olfactory bulb while $\mathrm{NPY}_{2.36}$ almost completely inhibited labeling in this structure (Fig. 1, Table 1). At the level of the striatum, ${ }^{125}$ I-PYY binding is potently inhibited by increasing concentrations of $\left[\mathrm{Pro}^{34}\right]-$ 


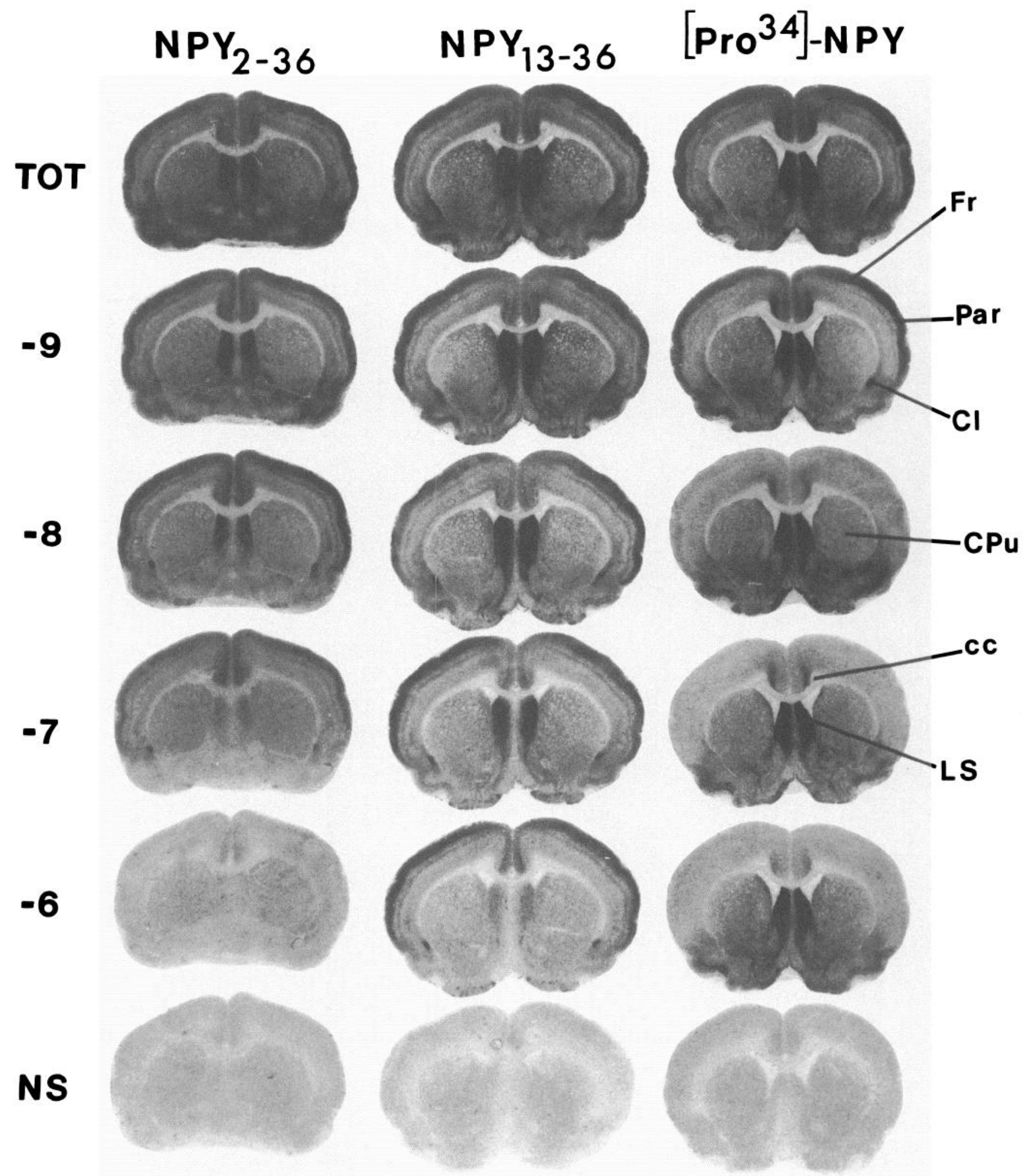

Figure 2. Photomicrographs of the autoradiographic distribution of ${ }^{125}$ I-PYY binding sites at the level of the striatum of the rat brain. Adjacent coronal sections were incubated with ${ }^{125}$ I-PYY alone (20-25 pM) (TOT) or in the presence of either $1 \mu \mathrm{M}$ pNPY (nonspecific binding, NS) or increasing concentrations (molar) of competitors such as NPY ${ }_{2-36}, \mathrm{NPY}_{13-36}$, or [Pro $\left.{ }^{34}\right]-\mathrm{NPY}$. Note that cortical labeling is sensitive to [Pro ${ }^{34}$ ]-NPY while subcortical binding is more sensitive to $\mathrm{NPY}_{13-36} . c c$, corpus callosum; $C l$, claustrum; $C P u$, caudate putamen; $F r$, frontal cortex; $L S$, lateral septum; Par, parietal cortex. 
$N P Y_{2-36}$

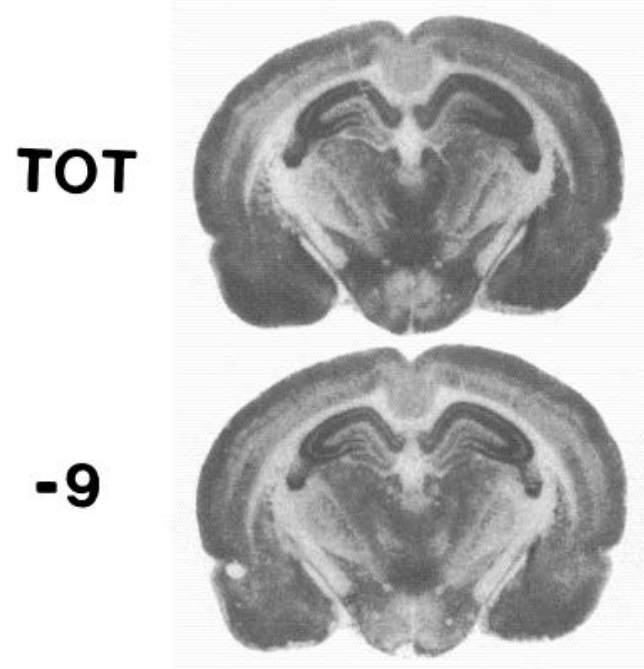

$-8$

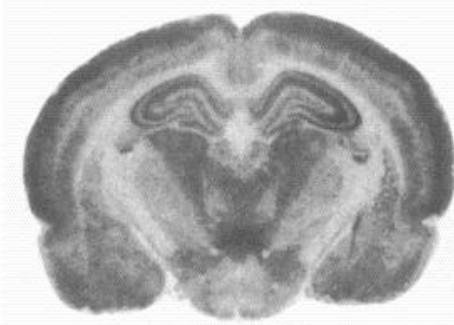

$-7$

$-6$
NPY $13-36$
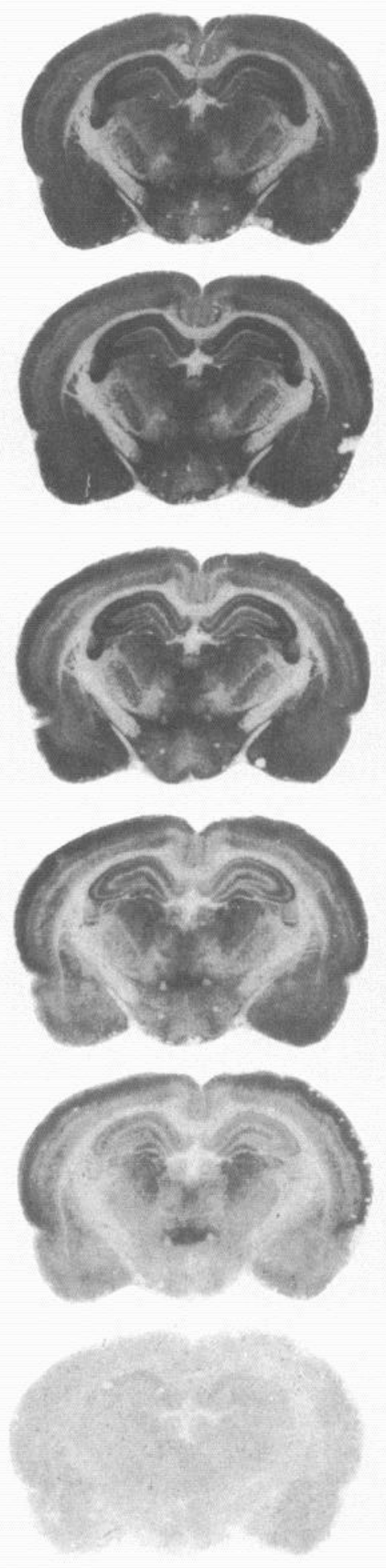

\section{$\left[\right.$ Pro $\left.^{34}\right]-$ NPY}
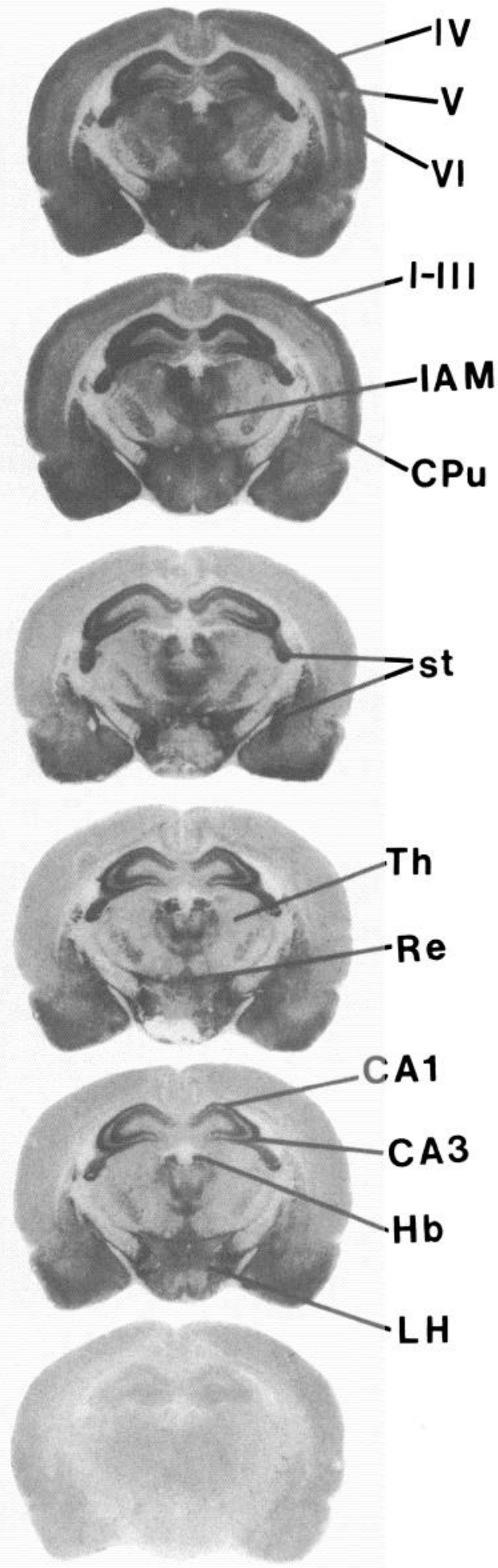

Figure 3. Photomicrographs of the autoradiographic distribution of ${ }^{125} \mathrm{I}-\mathrm{PYY}$ binding sites at the level of the hippocampal formation of the rat brain. Adjacent coronal sections were incubated with ${ }^{125} \mathrm{I}-\mathrm{PYY}$ alone (20-25 pM) (TOT) or in the presence of either $1 \mu \mathrm{M}$ pNPY (nonspecific binding, $N S$ ) or increasing concentrations (molar) of competitors such as NPY ${ }_{2-36}, \mathrm{NPY}_{13.36}$, or [Pro Pr4 $^{34}$-NPY. Note that cortical labeling is highly sensitive to [Pro $\left.{ }^{34}\right]$-NPY while hippocampal binding is competed by NPY ${ }_{2-36}$ and NPY ${ }_{13-36} . C A 1$ and $C A 3$, fields CA1 and CA3 of Ammon's horn of the hippocampus; $C P u$, caudate putamen; $H b$, habenular nucleus; $I A M$, interanteromedial thalamic nucleus; $L H$, lateral hypothalamic area; $R e$, reuniens thalamic nuclei; $s t$, stria terminalis; $T h$, thalamus; $I-V I$, cortical layers I-VI. 
Table 1. Quantitative autoradiographic distribution of ${ }^{25}$ I-PYY binding sites in rat brain

\begin{tabular}{|c|c|c|c|c|c|c|}
\hline \multirow[b]{3}{*}{ Brain region } & \multirow{3}{*}{$\begin{array}{l}\text { Total } \\
\text { specific } \\
\text { binding }\end{array}$} & \multicolumn{4}{|c|}{${ }^{125} \mathrm{I}-\mathrm{PYY}$ binding (fmol/mg tissue, wet weight) } & \multirow{3}{*}{$\begin{array}{l}\% \text { Putative } \\
Y_{1} \text { site } \\
\end{array}$} \\
\hline & & \multicolumn{2}{|c|}{$+\mathrm{NPY}_{13-36}\left(\mathrm{Y}_{2}\right)$} & \multicolumn{2}{|c|}{$+\left[\right.$ Pro $\left.^{34}\right]-N P Y\left(Y_{1}\right)$} & \\
\hline & & $10^{-7} \mathrm{M}$ & $10^{-6} \mathrm{M}$ & $10^{-8} \mathrm{M}$ & $10^{-7} \mathrm{M}$ & \\
\hline \multicolumn{7}{|l|}{ Anterior olfactory nucleus } \\
\hline Ventral part & $15.3 \pm 3.5$ & $12.9 \pm 2.6$ & $9.7 \pm 1.0$ & $6.3 \pm 0.6$ & $3.9 \pm 0.2$ & 59 \\
\hline Dorsal part & $14.1 \pm 3.2$ & $10.0 \pm 2.8$ & $6.6 \pm 0.4$ & $5.9 \pm 0.3$ & $4.7 \pm 0.5$ & 59 \\
\hline Medial part & $12.6 \pm 1.9$ & $9.2 \pm 1.6$ & $7.0 \pm 0.5$ & $7.2 \pm 0.7$ & $6.3 \pm 0.7$ & 43 \\
\hline Lateral part & $14.8 \pm 3.1$ & $8.8 \pm 1.4$ & $6.1 \pm 0.4$ & $7.8 \pm 1.4$ & $7.6 \pm 0.5$ & 48 \\
\hline \multicolumn{7}{|l|}{ Cortical area } \\
\hline \multicolumn{7}{|l|}{ Frontal cortex } \\
\hline Superficial layers & $8.9 \pm 1.7$ & $10.0 \pm 0.5$ & $8.1 \pm 0.3$ & $1.1 \pm 0.2$ & $0.1 \pm 0.1$ & 88 \\
\hline Mid layers & $4.0 \pm 0.3$ & $4.1 \pm 0.7$ & $3.1 \pm 1.5$ & $1.2 \pm 0.3$ & $0.4 \pm 0.2$ & 70 \\
\hline Deep layers & $3.9 \pm 0.5$ & $3.3 \pm 0.5$ & $2.4 \pm 0.9$ & $1.7 \pm 1.6$ & $1.2 \pm 0.4$ & 57 \\
\hline \multicolumn{7}{|l|}{ Parietal cortex } \\
\hline Superficial layers & $8.9 \pm 1.6$ & $9.5 \pm 1.4$ & $9.0 \pm 0.5$ & $1.2 \pm 0.4$ & $0.2 \pm 0.1$ & 87 \\
\hline Mid layers & $3.2 \pm 0.1$ & $3.6+0.6$ & $2.9 \pm 0.5$ & $0.6 \pm 1.3$ & $0.3 \pm 0.1$ & 82 \\
\hline Deep layers & $2.9 \pm 0.4$ & $2.6 \pm 0.3$ & $2.0 \pm 0.6$ & $1.4 \pm 0.5$ & $0.9 \pm 0.2$ & 52 \\
\hline Orbital cortex & $6.5 \pm 1.2$ & $7.2 \pm 0.9$ & $5.8 \pm 0.6$ & $1.5 \pm 0.4$ & $0.7 \pm 0.2$ & 77 \\
\hline Primary olfactory cortex & $6.8 \pm 1.9$ & $3.2 \pm 1.3$ & $1.6 \pm 0.7$ & $5.3 \pm 0.8$ & $6.0 \pm 0.6$ & 23 \\
\hline Piriform cortex & $10.2 \pm 2.4$ & $4.8 \pm 0.5$ & $1.4 \pm 0.2$ & $7.6 \pm 2.8$ & $6.6 \pm 0.7$ & 26 \\
\hline \multicolumn{7}{|l|}{ Basal ganglia } \\
\hline Lateral septum & $29.9 \pm 5.7$ & $8.6 \pm 3.4$ & $2.8 \pm 1.0$ & $26.8 \pm 5.8$ & $24.6 \pm 3.8$ & 11 \\
\hline Caudate putamen & $2.7 \pm 0.6$ & $1.8 \pm 0.6$ & $1.0 \pm 0.2$ & $2.0 \pm 0.6$ & $1.9 \pm 0.2$ & 26 \\
\hline Claustrum & $13.0 \pm 2.5$ & $12.9 \pm 1.9$ & $9.9 \pm 2.4$ & $4.6 \pm 1.6$ & $3.1 \pm 0.5$ & 65 \\
\hline Nucleus accumbens & $4.9 \pm 0.6$ & $2.6 \pm 0.7$ & $1.2 \pm 0.4$ & $4.6 \pm 1.2$ & $4.3 \pm 0.3$ & 7 \\
\hline Olfactory tubercle & $6.5 \pm 1.0$ & $4.5 \pm 0.7$ & $2.8 \pm 0.6$ & $5.4 \pm 1.4$ & $5.0 \pm 1.3$ & 17 \\
\hline \multicolumn{7}{|l|}{ Hippocampal formation } \\
\hline \multicolumn{7}{|l|}{ Oriens layer } \\
\hline CAl & $22.2 \pm 4.6$ & $3.8 \pm 0.6$ & $1.6 \pm 0.4$ & $17.4 \pm 4.6$ & $16.1 \pm 1.8$ & 22 \\
\hline $\mathrm{CA} 2$ & $31.1 \pm 5.7$ & $5.5 \pm 1.5$ & $2.1 \pm 0.7$ & $25.6 \pm 5.8$ & $23.4 \pm 2.1$ & 18 \\
\hline CA3 & $34.8 \pm 6.2$ & $6.5 \pm 0.8$ & $1.6 \pm 0.8$ & $32.3 \perp 4.5$ & $29.7 \pm 3.4$ & 7 \\
\hline \multicolumn{7}{|l|}{ Stratum radiatum } \\
\hline CAl & $17.0 \pm 3.4$ & $4.4 \perp 0.8$ & $2.0 \pm 0.6$ & $14.1 \pm 2.9$ & $13.2 \pm 1.6$ & 17 \\
\hline $\mathrm{CA} 2$ & $22.7 \pm 5.2$ & $4.9 \pm 1.3$ & $2.4 \pm 1.4$ & $20.8 \pm 3.5$ & $18.5 \pm 2.1$ & 8 \\
\hline $\mathrm{CA} 3$ & $29.4 \pm 4.9$ & $6.1 \pm 0.7$ & $2.9 \pm 1.1$ & $25.1 \pm 3.9$ & $23.5 \pm 2.2$ & 15 \\
\hline \multicolumn{7}{|l|}{ Dentate gyrus } \\
\hline Molecular layer & $4.2 \pm 1.9$ & $4.3 \pm 1.2$ & $3.1 \pm 1.1$ & $1.2 \pm 0.5$ & $0.9 \pm 0.3$ & 72 \\
\hline Granular layer & $3.1 \pm 1.5$ & $1.9 \pm 0.7$ & $1.3 \pm 0.4$ & $1.5 \pm 0.6$ & $1.1 \pm 0.5$ & 52 \\
\hline Stria terminalis & $25.8 \pm 4.6$ & $4.4 \pm 0.6$ & $1.0 \pm 0.4$ & $24.5 \pm 3.4$ & $23.1 \pm 2.9$ & 5 \\
\hline \multicolumn{7}{|l|}{ Thalamic nuclei } \\
\hline Habenular & $9.6 \pm 1.5$ & $2.9 \pm 0.7$ & $1.1 \pm 0.4$ & $9.2 \pm 1.2$ & $8.5 \pm 0.3$ & 4 \\
\hline Ventroposterior & $4.0 \pm 1.3$ & $1.9 \pm 0.3$ & $1.0 \pm 0.4$ & $2.6 \pm 0.7$ & $2.3 \pm 0.2$ & 35 \\
\hline Reuniens & $12.4 \pm 3.8$ & $11.6 \pm 1.1$ & $8.7 \pm 1.0$ & $4.2 \pm 0.9$ & $3.2 \pm 1.7$ & 66 \\
\hline Posterior & $4.1 \pm 1.1$ & $4.0 \pm 0.9$ & $2.2 \pm 0.3$ & $1.2 \pm 0.2$ & $0.8 \pm 0.3$ & 70 \\
\hline Interanteromedial & $8.6 \pm 2.0$ & $4.1 \pm 0.4$ & $2.9 \pm 0.3$ & $5.7 \pm 0.5$ & $4.9 \pm 0.6$ & 34 \\
\hline Laterodorsal & $6.1 \pm 2.0$ & $5.1 \pm 1.1$ & $3.7 \pm 0.4$ & $2.3 \pm 0.3$ & $1.9 \pm 0.8$ & 63 \\
\hline Mediodorsal & $10.1 \pm 2.5$ & $3.6 \pm 0.5$ & $1.5 \pm 0.8$ & $8.1 \pm 0.9$ & $7.4 \pm 0.8$ & 20 \\
\hline \multicolumn{7}{|l|}{ Hypothalamic nuclei } \\
\hline Dorsomedial & $5.2 \pm 0.5$ & $4.2 \pm 1.3$ & $2.4 \pm 0.7$ & $4.8 \pm 1.1$ & $4.6 \pm 0.9$ & 8 \\
\hline Ventromedial & $5.5 \pm 0.5$ & $2.6 \pm 0.4$ & $0.9 \pm 0.2$ & $4.7 \perp 0.6$ & $4.1 \pm 0.7$ & 15 \\
\hline Lateral & $7.1 \pm 0.8$ & $3.2 \pm 0.7$ & $1.1 \pm 0.4$ & $5.6 \pm 1.2$ & $5.8 \pm 0.5$ & 22 \\
\hline Amygdaloid complex & $6.9 \pm 2.2$ & $3.2 \pm 0.5$ & $1.2 \pm 0.3$ & $5.3 \pm 0.6$ & $3.4 \pm 0.4$ & 24 \\
\hline \multicolumn{7}{|l|}{ Brainstem nuclei } \\
\hline Posterodorsal tegmental & $9.4 \pm 2.1$ & $1.6 \pm 0.8$ & $1.2 \pm 0.3$ & $10.1 \pm 2 . i$ & $6.2 \pm 1.4$ & - \\
\hline Principal sensory trigeminal & $4.8 \pm 0.6$ & $1.4 \pm 0.3$ & $0.1 \pm 0.1$ & $4.7 \pm 0.5$ & $3.7 \pm 0.4$ & 3 \\
\hline
\end{tabular}


Table 1. Continued

\begin{tabular}{|c|c|c|c|c|c|c|}
\hline \multirow[b]{3}{*}{ Brain region } & \multirow{3}{*}{$\begin{array}{l}\text { Total } \\
\text { specific } \\
\text { binding }\end{array}$} & \multicolumn{4}{|c|}{${ }^{125} \mathrm{I}-\mathrm{PYY}$ binding (fmol/mg tissue, wet weight) } & \multirow{3}{*}{$\begin{array}{l}\% \text { Putative } \\
Y_{1} \text { site }\end{array}$} \\
\hline & & \multicolumn{2}{|c|}{$+N P Y_{13-36}\left(Y_{2}\right)$} & \multicolumn{2}{|c|}{$+\left[\right.$ Pro $\left.^{34}\right]-N P Y\left(Y_{1}\right)$} & \\
\hline & & $10^{7} \mathrm{M}$ & $10^{-6} \mathrm{M}$ & $10^{-8} \mathrm{M}$ & $10^{-7} \mathrm{M}$ & \\
\hline \multicolumn{7}{|l|}{ Cerebellum } \\
\hline Granular layer & $13.5 \pm 3.5$ & $1.0 \pm 0.3$ & $0.1 \pm 0.1$ & $12.7 \pm 3.4$ & $7.5 \pm 0.7$ & 6 \\
\hline Molecular layer & $2.1 \pm 0.6$ & $0.6 \pm 0.3$ & $0.4 \pm 0.2$ & $1.2 \pm 0.4$ & $0.8 \pm 0.3$ & 43 \\
\hline
\end{tabular}

NPY in the frontoparietal cortex and the claustrum but not in the caudate putamen, the lateral septum, and cortical areas below the rhinal sulcus (Fig. 2, Table 1). Almost the opposite situation is observed with the fragment NPY ${ }_{13-36}$, with ${ }^{125}$ I-PYY labeling being displaced by low concentrations of this competitor in the striatum and the septum but not in cortical areas (Fig. 2, Table 1).

At the level of the hippocampal formation (Fig. 3, Table 1), ${ }^{125}$ I-PYY labeling is again inhibited by the $Y_{1}$ agonist in cortical areas, while binding in the amygdaloid body and most subcortical structures is resistant to inhibition by $\left[\mathrm{Pro}^{34}\right]-N P Y$. In contrast, ${ }^{25}$ I-PYY labeling in the oriens layer and the stratum radiatum of the hippocampus as well as in the stria terminalis is highly sensitive to increasing concentrations of the $Y_{2}$ fragment (Fig. 3, Table 1). However, ${ }^{125} \mathrm{I}-\mathrm{PYY}$ binding in the dentate gyrus is not effected by NPY ${ }_{13-36}$ but very sensitive to the $Y_{1}$ agonist, even at low nanomolar concentrations (Fig. 3, Tablc 1). Thus, ${ }^{125} \mathrm{I}$-PYY sites in the dentate gyrus are most likely of a different subtype to those present in other sectors of the hippocampal formation. Most ${ }^{125}$ I-PYY binding sites in thalamic and hypothalamic nuclei are apparently more sensitive to the $Y_{2}$ than the $Y_{1}$ competitor (Fig. 3, Table 1). An exception is seen in the reuniens, posterior and laterodorsal thalamic nuclei, which are apparently enriched with $\left[\right.$ Pro $\left.^{34}\right]-N P Y / Y$, sites, whereas the habenular, interanteromedial, ventroposterior, and mediodorsal thalamic nuclei, and the lateral, dorsomedial and ventromedial hypothalamic nuclei are enriched with the $\mathrm{Y}_{2}$ subtype (Fig. 3, Table 1).

As in the olfactory bulb (Fig. 1), ${ }^{125}$ I-PYY binding in the cerebellum and various brainstem nuclei (Fig. 4) was found to be more susceptible to inhibition by NPY ${ }_{2-36}$ than by the shorter fragment $N P Y_{13-36}$. The $Y_{1}$ agonist was much weaker than the two NPY fragments in these same areas.

\section{Characterization of ${ }^{25} I-P Y Y$ binding sites in membranes from rat brain homogenates}

Membranes prepared from various regions of the rat brain revealed that the homologs PYY and NPY, the fragments NPY ${ }_{36}$ and NPY ${ }_{13-36}$, and the analog [ $\left[\mathrm{Lcu}^{34}, \mathrm{Pro}^{34}\right]-\mathrm{NPY}$ inhibited specific ${ }^{125} \mathrm{I}-\mathrm{PYY}$ binding in a concentration-dependent manner (Figs. 5, 6). The rank order of potency in olfactory bulb, striatal, hippocampal, and cerebellar homogenates revealed $P Y Y>N P Y$ $>\mathrm{NPY}_{2-36} \geq \mathrm{NPY}_{13-36} \gg\left[\mathrm{Leu}^{31}{ }^{\text {,Pro }}{ }^{34}\right]-\mathrm{NPY}$ (Fig. 5). A different profile of competition was detected in the frontoparietal cortex (Fig. 6). In this preparation, a clearly biphasic profile is seen with the $Y_{1}$ agonist [Leu ${ }^{31}$, Pro $^{34}$ ]-NPY. At low concentrations (nanomolar), the ligand selectivity pattern showed PYY $>$ NPY $=\left[\mathrm{Lcu}^{31}, \mathrm{Pro}^{34}\right]-\mathrm{NPY}>\mathrm{NPY}_{2-36}>\mathrm{NPY}{ }_{13-36}$, whilc at higher concentrations (micromolar), the $Y_{1}$ agonist was only weakly active, with $P Y Y>p N P Y>N P Y_{2-36} \geq N P Y_{13-36}>\left[I_{e u^{31}}\right.$, Pro $\left.^{34}\right]-$ NPY (Fig. 6). This is also clearly shown in Figure 7. For example, while the competition profile of the fragment NPY ${ }_{13-36}$ appears to be identical in membranes prepared from either the olfactory bulb, striatum, hippocampus, or cerebellum, it was much less potent in cortical preparations (Fig. $7 A$ ). In contrast, the $\mathrm{Y}_{1}$ agonist $\left[\mathrm{Leu}^{31}\right.$, Pro $\left.^{34}\right]$-NPY inhibited ${ }^{125}$ I-PYY binding with a clcarly biphasic profile, especially in the frontoparietal cortex area, and to a lesser extent in the olfactory bulb (Fig. $7 B$ ). This suggests the existence of different classes or affinity states of ${ }^{125} I-$ PYY binding sites in these brain regions. The low Hill coefficient values observed for all competitors also supports this hypothesis (Tables 2-6).

\begin{tabular}{|c|c|c|c|c|c|}
\hline Regions & $n_{\mathrm{H}}$ & $K_{\mathrm{D} 1}(\mathrm{pM})$ & $K_{\mathrm{D} 2}(\mathrm{pM})$ & $K_{\mathrm{D} 1} / K_{\mathrm{D} 2}$ & $\% \mathrm{RI}$ \\
\hline Olfactory bulb & $0.58 \pm-0.05$ & $24 \pm 13$ & $900 \pm 200$ & 0.026 & $59 \pm 8$ \\
\hline Frontoparietal cortex & $0.57 \pm 0.03$ & $18 \pm 10$ & $1300 \pm 400$ & 0.014 & $30 \pm 6$ \\
\hline Striatum & $0.61 \pm 0.04$ & $4 \pm 4$ & $400 \pm 200$ & 0.010 & $32 \pm 5$ \\
\hline Hippocampus & $0.61 \pm 0.02$ & $10 \pm 7$ & $300 \pm 200$ & 0.033 & $49 \pm 6$ \\
\hline Cerebellum & $0.54 \pm 0.05$ & $12 \pm 9$ & $600 \pm 200$ & 0.020 & $59 \pm 9$ \\
\hline
\end{tabular}

Data (means \pm SEM of four to six determinations) were fitted to a one- or a two-binding-site model by a nonlinear method of analysis using the Lundon Software COMPETITION data analysis program. The goodness of fit between the two models was tested by $F$ test $(p<0.05)$. $n_{\mathrm{H}}$ represents the Hill coefficient determined by a linear method of analysis. $K_{\mathrm{D},}$ and $K_{\mathrm{D} 2}$ represent the affinity of PYY for the high-and low-affinity site, respectively. $K_{\mathrm{D} 1} / K_{\mathrm{D} 2}$ is the ratio of the affinities of the two binding sites. $\%$ R 1 represents the percentage of sites in the high-affinity mode. 


\section{$N P Y_{2-36}$}

TOT

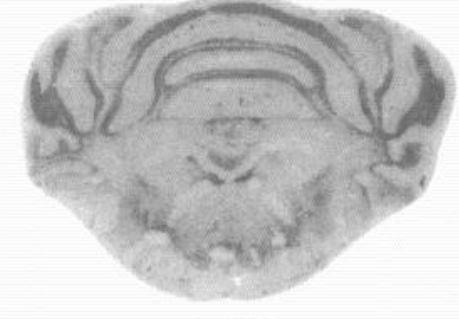

$-9$

$-8$

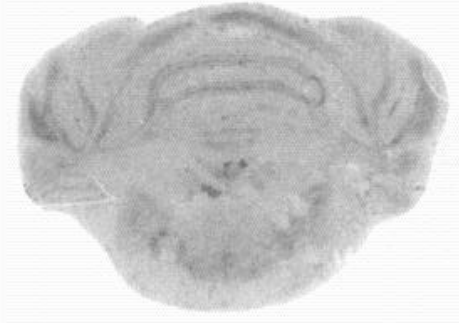

$-7$
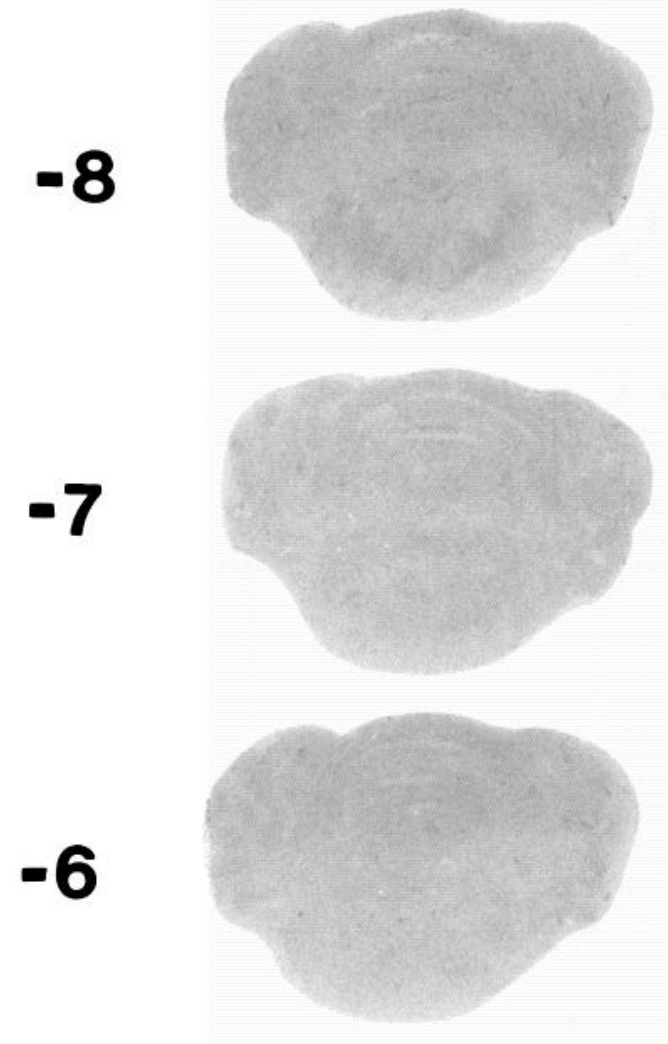

NS
NPY $13-36$
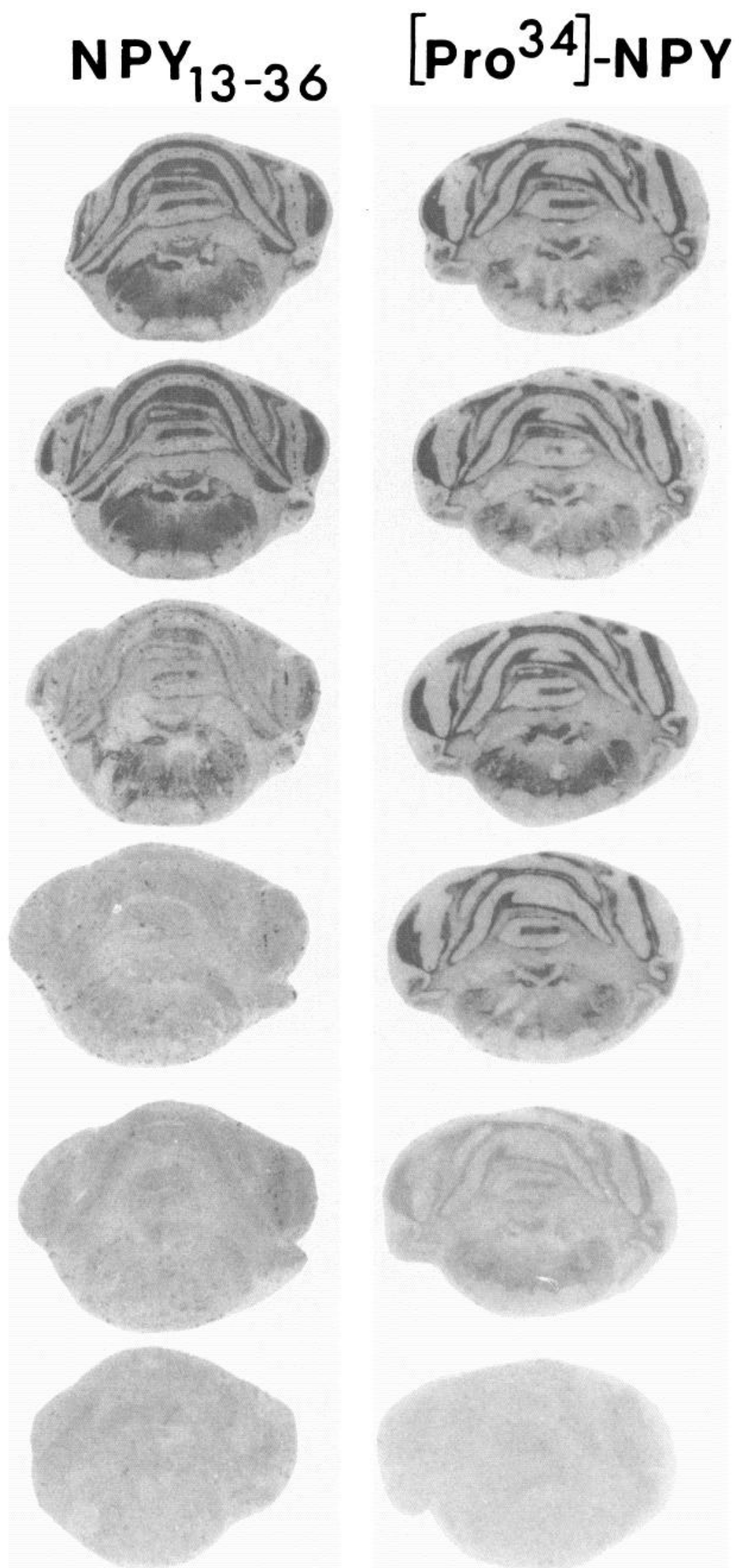

Figure 4. Photomicrographs of the autoradiographic distribution of ${ }^{125}$ I-PYY binding sites at the level of the cerebellum of the rat brain. Adjacent coronal sections were incubated with ${ }^{125}$ I-PYY alone (20-25 pM) (TOT) or in the presence of either $1 \mu \mathrm{M}$ pNPY (nonspecific binding, NS) or increasing concentrations (molar) of competitors such as NPY ${ }_{2-36}, \mathrm{NPY}_{13-36}$, or [Pro ${ }^{34}$ ]-NPY. Note that the cerebellum labeling is most sensitive to both $\mathrm{NPY}_{2-36}$ and NPY ${ }_{13-36}$ but not to [Pro $\left.{ }^{34}\right]-\mathrm{NPY}$. 

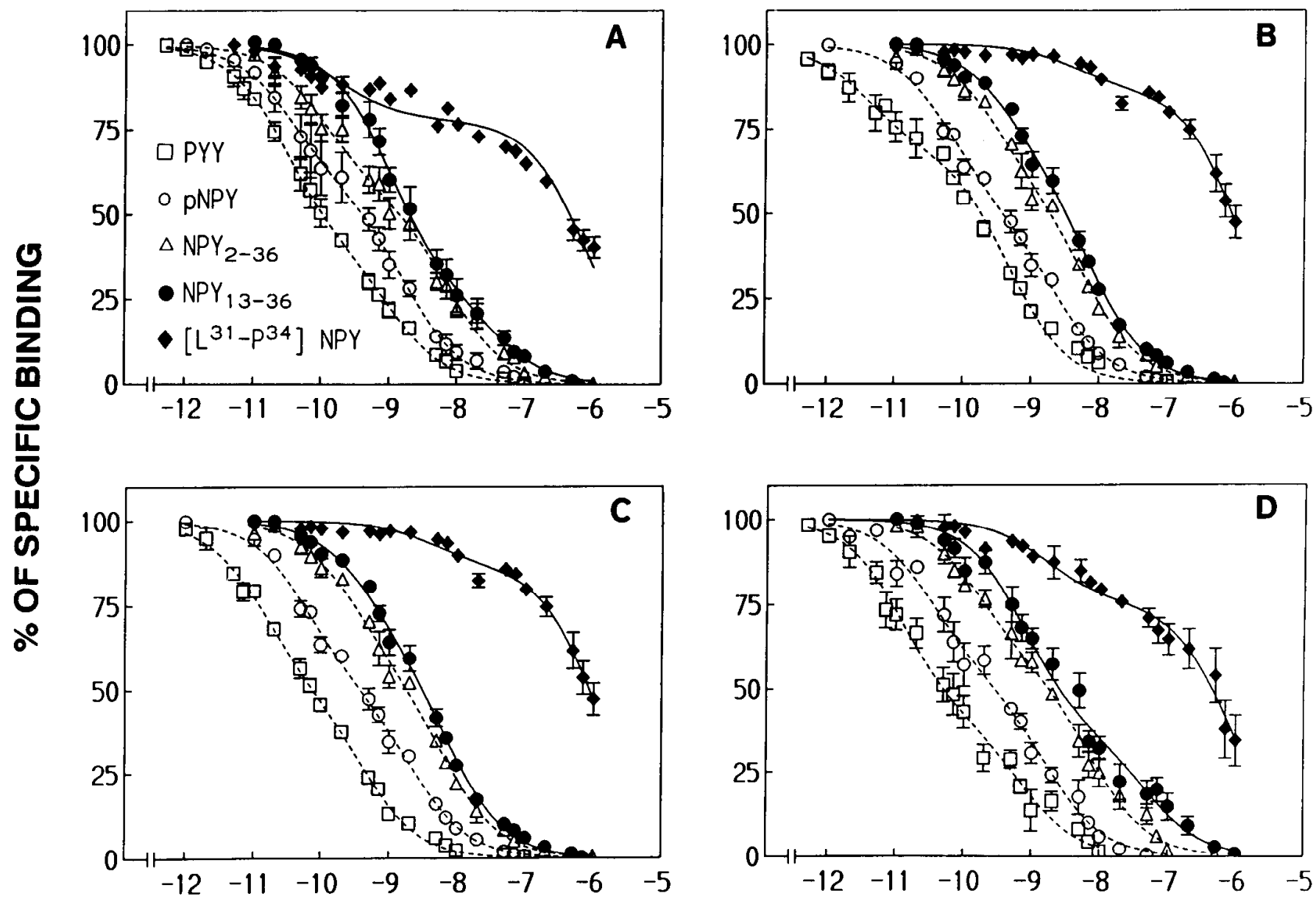

\section{LOG OF CONCENTRATION}

Figure 5. Competition binding profiles of NPY-related peptides against specific ${ }^{125}$ I-PYY labeling in rat brain membrane homogenates of the olfactory bulb $(A)$, striatum $(B)$, hippocampus $(C)$, and cerebellum $(D)$. Similar competition profiles were obtained in each of these four regions. Each point represents the mean \pm SEM of data obtained from four to seven experiments, each performed in triplicate and expressed as the percentage of specific binding.

In fact, binding data were all best fitted using a two-site model $(p<0.05)$. The apparent affinities $\left(K_{D}\right)$ of the high- and lowaffinity components detected using PYY itself varied between 4-24 pм and 340-1350 pм, depending upon the regions studied (Table 2). Similar results were obtained with NPY (Table 3). The deletion of the tyrosine residue in position $1\left(\mathrm{NPY}_{2-36}\right)$ decreased the affinity by three- to fivefold for the high-as well as for the low-affinity binding components in all membrane preparations except the frontoparietal cortex; in this tissue, a greater (15-fold) decrease is observed for the low-affinity site (Table 4). Interestingly, the shorter C-terminal fragment NPY ${ }_{13-36}$ demonstrated different affinities for the two binding components depending upon the brain region studied. In striatal and hippocampal membrane homogenates, $\mathrm{NPY}_{13-36}$ possessed rela-

Table 3. Binding parameters of the homolog pNPY derived from competition curves against ${ }^{125}$ I-PYY in various regions of the rat brain

\begin{tabular}{llllll} 
Regions & $n_{\mathrm{H}}$ & $K_{\mathrm{D} 1}(\mathrm{pM})$ & $K_{\mathrm{D} 2}(\mathrm{pM})$ & $K_{\mathrm{D} 1} / K_{\mathrm{D} 2} \% \mathrm{R} 1$ \\
\hline Olfactory bulb & $0.61 \pm 0.07$ & $31 \pm 12$ & $1500 \pm 500$ & 0.021 & $44 \pm 5$ \\
Frontoparietal cortex & $0.67 \pm 0.08$ & $46 \pm 10$ & $1100 \pm 300$ & 0.042 & $17 \pm 8$ \\
Striatum & $0.70 \pm 0.03$ & $70 \pm 40$ & $1500 \pm 600$ & 0.047 & $35 \pm 7$ \\
Hippocampus & $0.64 \pm 0.05$ & $52 \pm 15$ & $1900 \pm 500$ & 0.027 & $50 \pm 4$ \\
Cerebellum & $0.62 \pm 0.04$ & $35 \pm 11$ & $1300 \pm 400$ & 0.027 & $47 \pm 6$
\end{tabular}

Data (means \pm SEM of four to seven determinations) were fitted to a one- or a two-binding-site model by a nonlinear method of analysis using the Lundon Software competition data analysis program. The goodness of fit between the two models was tested by $F$ test $(p<0.05) . n_{14}$ represents the Hill coefficient determined by a linear method of analysis. $K_{\mathrm{t}}$ and $K_{\mathrm{D} 2}$ represent the affinity of $\mathrm{pNPY}$ for the high- and low-affinity site, respectively. $K_{\mathrm{D} 21} / K_{\mathrm{D} 2}$ is the ratio of the affinities of the two binding sites. $\% \mathrm{R} 1$ represents the percentage of sites in the high-affinity mode. 


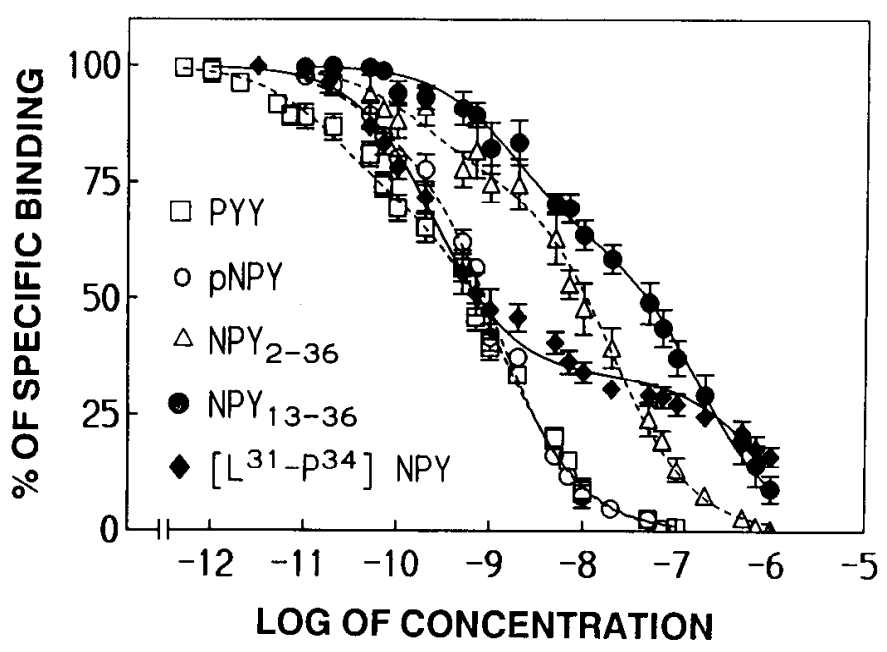

Figure 6. Competition binding profile of NPY-related peptides against specific ${ }^{125}$ I-PYY labeling in rat frontoparietal cortex membrane homogenates. In contrast to other tissues, [Leu ${ }^{31}$, Pro $\left.^{34}\right]$-NPY potently competed for binding in this area. Each point represents the mean \pm SEM of data obtained from four to eight experiments, each performed in triplicate and expressed as the percentage of specific binding.

tively similar affinities for the two binding components (Table 5), while important differences were detected in the olfactory bulb (30-fold) and the cerebellum (over 60-fold) (Table 5). An even greater dissociation (almost 100 -fold) between the highand low-aftinity binding components is observed for the frontoparietal cortex (Table 5). Moreover, the apparent affinities of the $Y_{1}$ agonist $\left[\mathrm{Leu}^{31}\right.$,Pro $\left.{ }^{34}\right]-N P Y$ for the high- and low-affinity binding components are dramatically different with values in the sub- to low nanomolar range on the first binding site but only in the micromolar range for the second portion of the competition curves (Table 6). This is especially evident in the frontoparietal cortex, a region enriched with the putative $Y_{1}$ receptor subtype (Table 6). In the other regions, the proportion of $Y_{1}$ sites is apparently smaller, the lowest amount being detected in the hippocampal formation (Table 6).

In order to investigate further the possible heterogeneity of ${ }^{125}$ I-PYY-labeled binding sites, we performed a series of experiments in the presence of $10 \mathrm{~nm}\left[\mathrm{Leu}^{31}\right.$, Pro $\left.^{34}\right]-\mathrm{NPY}$, a concentration known to be sufficient to block most, if not all, binding

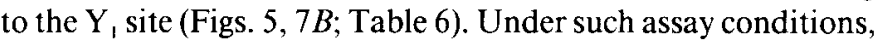
the competition profile is still best fitted to a two-site model ( $p$ $<0.05$ ) in regions such as the hippocampus and the striatum
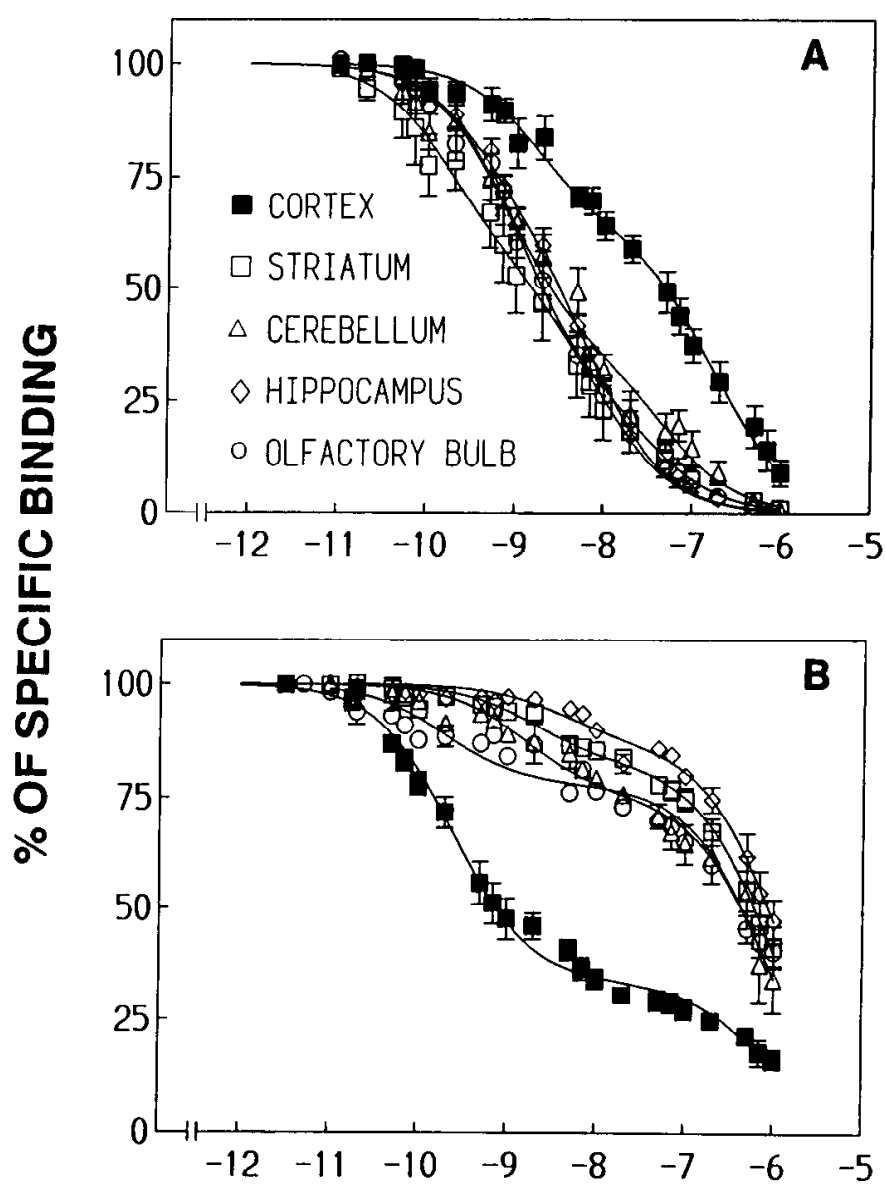

\section{LOG OF CONCENTRATION}

Figure 7. Comparative competition hinding profiles of NPY ${ }_{13.30}(A)$ and $\left[\mathrm{Leu}^{31}\right.$, Pro $\left.^{34}\right]-N P Y(B)$ against specific ${ }^{125}$ I-PYY labeling in membrane homogenates derived from various regions of the rat brain. Note that while NPY $_{13-56}$ is less potent in the cortical area as compared to all other regions, the opposite situation is observed for the $Y_{1}$ analog $\left[\right.$ Leu $^{3 \mathrm{t}}$, Pro $\left.^{34}\right]-N P Y$. Each point represents the mean \pm SEM of data obtained from four to eight experiments, each performed in triplicate and expressed as the percentage of specific binding.

(Table 7). Similarly, Hill coefficients remained below unity, suggesting further heterogeneity of ${ }^{125} \mathrm{I}-\mathrm{PYY}$-labeled sites in these regions, even in the presence of a saturating concentration of the $Y$, blocker.

Table 4. Binding parameters of the fragment $\mathrm{NPY}_{2-36}$ derived from competition curves against ${ }_{125} \mathrm{I}-\mathrm{PYY}$ in various regions of the rat brain

\begin{tabular}{lllrrr} 
Regions & $n_{\mathrm{H}}$ & $K_{\mathrm{D} 1}(\mathrm{pM})$ & \multicolumn{1}{c}{$K_{\mathrm{D} 2}(\mathrm{pM})$} & \multicolumn{1}{c}{$K_{\mathrm{D} 1} / K_{\mathrm{D} 2} \% \mathrm{R} 1$} \\
\hline Olfactory bulb & $0.56 \pm 0.06$ & $130 \pm 20$ & $6200 \pm 1000$ & 0.021 & $45 \pm 6$ \\
Frontoparietal cortex & $0.59 \pm 0.03$ & $150 \pm 50$ & $23,000 \pm 800$ & 0.006 & $31 \pm 7$ \\
Striatum & $0.63 \pm 0.03$ & $120 \pm 60$ & $4400 \pm 2100$ & 0.027 & $49 \pm 5$ \\
Hippocampus & $0.58 \pm 0.05$ & $240 \pm 100$ & $5500 \pm 1300$ & 0.043 & $44 \pm 5$ \\
Cerebellum & $0.61 \pm 0.06$ & $140 \pm 40$ & $6200 \pm 2200$ & 0.023 & $43 \pm 6$
\end{tabular}

Data (means \pm SEM of four or five determinations) were fitted to a one- or a two-binding-site model by a nonlinear method of analysis using the Lundon Software COMPETITION data analysis program. The goodness of fit between the two models was tested by $F$ test $(p<0.05)$. $n_{\mathrm{H}}$ represents the Hill coefficient determined by a lincar method of analysis. $K_{\mathrm{D} 1}$ and $K_{\mathrm{D}}$, represent the affinity of $\mathrm{NPY}_{2-36}$ for the high- and low-affinity site, respectively. $K_{\mathrm{Dl}} / K_{\mathrm{D}, 2}$ is the ratio of the affinities of the two binding sites. \% R 1 represents the percentage of sites in the high-affinity mode. 
Table 5. Binding parameters of the fragment $N Y_{13-36}$ derived from competition curves against

${ }_{125}$ I-PYY in various regions of the rat brain

\begin{tabular}{|c|c|c|c|c|c|}
\hline Regions & $n_{\mathrm{H}}$ & $K_{\mathrm{D} 1}(\mathrm{pM})$ & $K_{\mathrm{I} 22}(\mathrm{pm})$ & $K_{\mathrm{D} 1} / K_{\mathrm{D} 2}$ & $\% \mathrm{R} 1$ \\
\hline Olfactory bulb & $0.59 \pm 0.04$ & $840 \pm 300$ & $34,000+10,000$ & 0.0025 & $69 \pm 7$ \\
\hline Frontoparietal cortex & $0.46 \pm 0.04$ & $1500 \pm 500$ & $175,000 \pm 69,000$ & 0.009 & $41 \pm 6$ \\
\hline Striatum & $0.59 \pm 0.03$ & $240 \pm 100$ & $7300 \pm 2400$ & 0.032 & $48 \pm 7$ \\
\hline Hippocampus & $0.52 \pm 0.05$ & $410 \pm 210$ & $6400 \pm 1900$ & 0.064 & $37 \pm 6$ \\
\hline Cerebellum & $0.54 \pm 0.06$ & $600 \pm 240$ & $39,000 \pm 9000$ & 0.015 & $63 \pm 7$ \\
\hline
\end{tabular}

Data (means \pm SEM of four to six determinations) were fitted to a one- or a two-binding-site model by a nonlinear method of analysis using the Lundon Software cOMPETITION data analysis program. The goodness of fit between the two models was tested by $F$ test $(p<0.05) . n_{11}$ represents the Hill coefficient determined by a linear method of analysis. $K_{\mathrm{D}}$ and $K_{\mathrm{D}, 2}$ represent the affinity of $\mathrm{NPY}_{13.16}$ for the high- and low-affinity site, respectively. $K_{\mathrm{D}, 1} / K_{\mathrm{D} 2}$ is the ratio of the affinities of the two binding sites. \% RI represents the percentage of sites in the high-affinity mode.

\section{Discussion}

The major finding of the present study relates to the clear demonstration of the differential distribution of the $Y_{1}$ and $Y_{2} N P Y$ receptor subtypes in the rat brain. For example, $Y_{1}$ receptors are especially concentrated in cortical areas while one of the highest proportions of $Y_{2}$ sites is seen in the hippocampal formation. Moreover, the apparent resistance of ${ }^{125} I-P Y Y-$ labeled sites to inhibition by [Pro $\left.{ }^{34}\right]-N P Y\left(Y_{1}\right)$ and $N P Y_{13-36}\left(Y_{2}\right)$, but not $\mathrm{NPY}_{2-36}$, in the olfactory bulb suggests further receptor heterogeneity.

As reported earlier (Inui et al., 1988, 1998; Lynch et al., 1989; Martel et al., 1990a; Quirion et al., 1990; Rosier et al., 1990), the total population of ${ }^{125}$ I-PYY sites is widely, but discretely, distributed in the rat brain, with high densities of labeling present, among other regions, in hippocampal and cortical areas. Using increasing concentrations of the selective $Y_{1}$ competitor [Pro $\left.{ }^{34}\right]-N P Y$, we confirmed and extended carlier findings (Dumont et al., 1990; Aicher et al., 1991) on the preferential localization of $\mathrm{Y}$, receptors in the rat CNS. In addition to superficial laminar cortical areas above the rhinal nucleus, comparatively high levels of $Y_{1}$ sites are seen in the claustrum, the dentate gyrus of the hippocampal formation, and the reuniens nucleus of the thalamus. Lower but still detectable amounts of $Y_{1}$ sites are also present in various thalamic and hypothalamic nuclei.

The functional relevance of the $Y$, receptor class in the brain remains to be fully established. However, their concentrations in cortical areas suggest a modulatory role in the integration of cortical functions, especially since the cortex is enriched with NPY-like-immunoreactive materials (Chronwall et al., 1985;
O'Donohue et al., 1985; DeQuidt and Emson, 1986a,b). In that regard, it is of interest to note that direct injections of NPYlike peptides in cortical areas, through the activation of phosphoinositide turnover (Hinson et al., 1988; Widdowson and Halaris, 1990a), can increase the respiratory quotient and food intake (McGregor et al., 1990). Thus, cortical areas such as the sulcal prefrontal cortex, in association with hypothalamic nuclei (Stanley and Leibowitz, 1984; Stanley et al., 1985; Kalra et al., 1988, 1990; Jolicoeur et al., 1991 b; Leibowitz and Alexander, 1991), can, via the stimulation of $Y_{1}$ receptors, modulate these behaviors in the rat. The possible functional role of $Y$, sites in other areas such as the dentate gyrus and the reuniens nucleus remains to be established. To date, most studies, especially those related to the hippocampus, have focused on $\mathrm{Y}_{2}$-enriched areas such as the stratum radiatum of the CAl (Colmers et al., 1987, $1988,1991)$ or the pyramidal cell layer of the CA3 subfield (Monnet et al., 1992). However, the recent cloning of the $Y_{1}$ receptor class (Eva et al., 1990; Herzog et al., 1992; Yee et al., 1992) should facilitate further evaluation of its precise role in the CNS, as well as reveal the mechanisms involved in the regulation of its expression.

In other brain regions, we first assumed that the majority of ${ }^{125} \mathrm{I}-\mathrm{PYY}$ binding represented labeling of the $\mathrm{Y}_{2}$ subtype. This was based on the relatively high potencies of $\mathrm{C}$-terminal fragments such as NPY ${ }_{13-36}$ to compete for specific ${ }^{125} \mathrm{I}-\mathrm{PYY}$ or ${ }^{125} \mathrm{I}-$ NPY labeling (Dumont et al., 1990; Aicher et al., 1991). However, the more detailed analysis performed here using selected brain region homogenates clearly revealed the biphasic nature of the competition profiles, with Hill coefficients significantly lower than unity, even in the presence of a blocking concentration of the $Y_{1}$ agonist $\left[\mathrm{Leu}^{31}, \mathrm{Pro}^{34}\right]-\mathrm{NPY}$ (see Table 7). The

Table 6. Binding parameters of the analog $\left[\operatorname{Leu}^{31}, \mathrm{Pro}^{34}\right]-\mathrm{NPY}$ derived from competition curves against ${ }^{125} \mathrm{I}-\mathrm{PYY}$ in various regions of the rat brain

\begin{tabular}{llclll} 
Regions & $n_{\mathrm{H}}$ & $K_{\mathrm{D} 1}(\mathrm{pM})$ & $K_{\mathrm{D} 2}(\mathrm{pM})$ & $K_{\mathrm{D} 1} / K_{\mathrm{D} 2} \% \mathrm{R} 1$ \\
\hline Olfactory bulb & $0.38 \pm 0.07$ & $170 \pm 100$ & $780,000 \pm 150,000$ & 0.0002 & $24 \pm 4$ \\
Frontoparietal cortex & $0.31 \pm 0.03$ & $210 \pm 90$ & $660,000 \pm 230,000$ & 0.0003 & $67 \pm 5$ \\
Striatum & $0.32 \pm 0.06$ & $1650 \pm 500$ & $820,000 \pm 380,000$ & 0.002 & $18 \pm 3$ \\
Hippocampus & $0.33 \pm 0.04$ & $3500 \pm 1500$ & $980,000 \pm 270,000$ & 0.004 & $13 \pm 4$ \\
Cerebellum & $0.32 \pm 0.05$ & $1300 \pm 400$ & $710,000 \pm 310,000$ & 0.002 & $25 \pm 5$
\end{tabular}

Data (means \pm SEM of four to eight determinations) were fitted to a one- or a two-binding-site model by a nonlinear method of analysis using the Lundon Software cOMPETITION data analysis program. The goodness of fit between the two models was tested by $F$ test $(p<0.05)$. $n_{\mathrm{H}}$ represents the Hill cocfficient determincd by a linear method of analysis. $K_{\mathrm{D},}$

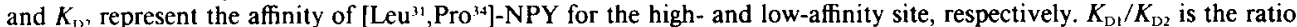
of the affinities of the two binding sites. $\% \mathrm{R} 1$ represents the percentage of sites in the high-affinity mode. 


\begin{tabular}{|c|c|c|c|c|}
\hline Regions & $n_{\mathrm{H}}$ & $K_{\mathrm{D} 1}(\mathrm{pM})$ & $K_{\mathrm{D} 2}(\mathrm{pM})$ & $\%$ R 1 \\
\hline \multicolumn{5}{|l|}{ Striatum } \\
\hline Control & $0.61 \pm 0.04$ & $4 \pm 4$ & $400 \pm 200$ & $32 \pm 5$ \\
\hline$+\left[\right.$ Leu $^{31}$, Pro $\left.^{34}\right]-$ NPY & $0.58 \pm 0.06$ & $1 \pm 2$ & $120 \pm 80$ & $14 \pm 6$ \\
\hline \multicolumn{5}{|l|}{ Hippocampus } \\
\hline Control & $0.61 \pm 0.02$ & $10 \pm 7$ & $300 \pm 200$ & $49 \pm 6$ \\
\hline$+\left[\right.$ Leu $^{31}$, Pro $\left.^{34}\right]-$ NPY & $0.57 \pm 0.03$ & $9 \pm 6$ & $180 \pm 75$ & $45 \pm 7$ \\
\hline
\end{tabular}

Data (means \pm SEM of four to eight determinations) were fitted to a one- or a two-binding-site model by a nonlinear method of analysis using the Lundon Software COMPETITION data analysis program. The goodness of tit between the two models was tested by $F$ test $(p<0.05)$. $n_{\mathrm{H}}$ represents the Hill coefficient determined by a linear method of analysis. $K_{\mathrm{r}, \mathrm{I}}$ and $K_{\mathrm{D} 2}$ represent the affinity of PYY for the high- and low-affinity site, respectively. \% R1 represents the percentage of sites in the high-affinity mode observed in presence and absence of a 10 nM blocking concentration of [Leu ${ }^{31}$, Pro $\left.^{34}\right]-$ NPY.

biphasic nature of the competition curves could relate to the existence of a single class of NPY receptors (e.g., $Y_{2}$ ) under different affinity states. This possibility has already been suggested for various preparations including the porcine hippocampus (Inui et al., 1988, 1989), dorsal root ganglia (Walker et al., 1988), whole rat brain (Walker and Miller, 1988), and cervical vagus nerve (Corp and Smith, 1991). However, the fact that we observed markedly different ratios between the high- and lowaffinity components $\left(K_{\mathrm{D} 1} / K_{\mathrm{D} 2}\right)$ for the selective $\mathrm{Y}_{1}$ agonist $\left[\mathrm{Leu}^{31}\right.$, Pro $\left.^{34}\right]$-NPY and the $\mathrm{Y}_{2}$ fragment NPY ${ }_{13-36}$ tends to support an alternate hypothesis, namely, the existence of further NPY receptor heterogeneity.

In support of this concept, some studies have already suggested the existence of either PP (Whitcomb et al., 1990; Adamo and Hazelwood, 1991) or atypical NPY/ $\sigma$ (Roman et al., 1989; Monnet et al., 1992) receptors for which both PYY and NPY demonstrate high affinities in the mammalian CNS. We are currently investigating these various possibilities using preferential ligands for each additional putative receptor class. Molecular information concerning the presence of $Y_{2}$ receptors in various brain regions and tissues should also help to clarify this issue, although the cloning of this receptor class has yet to be reported.

The widespread anatomical distribution of the "so-called" $Y_{2}$ receptors reported here suggests its important role(s) in the mediation of the biological effects induced by NPY and related peptides. Various CNS actions of this peptide family have already been characterized as belonging to this receptor class (see Dumont et al., 1992, for a recent review). It remains to be established if, in fact, these effects demonstrate an identical pharmacological profile. This can only be achieved using an extensive series of selective NPY/PYY fragments and analogs. This should reveal the possible functional heterogeneity of the now broadly classified $Y_{2}$ receptor class.

It is also of interest that $\mathrm{NPY}_{2-36}$ appears to be relatively more potent in competing for ${ }^{125} \mathrm{I}-\mathrm{PYY}$ binding in regions such as the olfactory bulb and the cerebellum. This may relate to the existence in these areas of an atypical site, which possesses a high affinity for the full NPY sequence as well as the NPY ${ }_{2+36}$ fragment, an observation already reported in regard to the effects of NPY and homologs on feeding behaviors (Magdalin et al., 1989; Jolicoeur et al., 1991b).

In summary, $Y_{1}$ and $Y_{2}$ receptor subtypes are discretely, but differentially, distributed in the rat brain. $Y_{t}$ sites are especially concentrated in cortical areas, in the dentate gyrus of the hip- pocampal formation, and in a few other nuclei, while $Y_{2}$ binding sites are more broadly distributed, being enriched in most regions. Moreover, it appcars that sitcs classified as $Y_{2}$ receptors may constitute a heterogeneous population of receptors. Experiments are currently in progress to investigate fully this possibility using subtype selective analogs and molecular biological approaches. This work may have an important impact on our understanding of the functional role of NPY and related peptides in the brain.

\section{References}

Adamo ML, Hazelwood RL (1991) Specific neuropeptide $Y$ binding sites in chicken brain. Am J Physiol 260:E839-E845.

Aguirre JA, Fuxe F, Agnati LF, Von Euler G (1990) Centrally injected neuropeptide $Y(13-36)$ produces vasopressor effects and antagonizes the vasodepressor action of neuropeptide $Y(1-36)$ in the awake male rat. Neurosci Lett 118:5-8.

Aicher SA, Springston M, Berger SB, Reis DJ, Wahlestedt C (1991) Receptor-selective analogs demonstrate NPY/PYY receptor heterogeneity in rat brain. Neurosci Lett 130:32-36.

Busch-Sorensen M, Sheikh SP, O'Hare M, Tortora O, Schwartz TW, Gammeltoft S (1989) Regional distribution of neuropeptide $Y$ and its receptor in the porcine central nervous system. J Neurochem 52: 1545-1552.

Chang RSL, Lotti VJ, Chen TB, Cerino DJ, Kling PJ (1985) Neuropeptide Y (NPY) binding sites in rat brain labeled with ${ }^{125}$ I-BoltonHunter NPY: comparative potencies of various polypeptides on brain NPY binding and biological responses in the rat vas deferens. Life Sci 37:2111-2122.

Chang RSL, Lotti VJ, Chen TB (1986) Increased neuropeptide Y (NPY) receptor binding in hippocampus and cortex of spontaneous hypertensive (SH) rats compared to normotensive (WKY) rats. Neurosci Lett 67:275-278.

Chang RSL, Lotti VJ, Chen TB (1988) Specific [ $\left.{ }^{3} \mathrm{H}\right]$ propionyl-neuropeptide $Y$ (NPY) binding in rabbit aortic membranes: comparisons with binding in rat brain and biological responses in rat vas deferens. Biochem Biophys Res Commun 151:1213-1219.

Chan-Palay V, Vasargil G, Hamid Q, Polak JM, Palay SL (1988) Simultaneous demonstration of neuropeptide $Y$ gene expression and peptide storage in single neurons of the human brain. Proc Natl Acad Sci USA 85:3213-3215.

Chronwall BM, DiMaggio DA, Massari VJ, Pickel VM, Ruggiero DA, O'Donohue TL (1985) The anatomy of neuropeptide $Y$ containing neurons in rat brain. Neuroscience 15:1159-1181.

Colmers WF, Lukowiak K, Pittman QJ (1987) Presynaptic action of neuropeptide $Y$ in area $C A 1$ of the rat hippocampal slice. J Physiol (Lond) 383:285-299.

Colmers WF, Lukowiak K, Pittman QJ (1988) Neuropeptide Y action in the rat hippocampal slice: site and mechanism of presynaptic inhibition. J Neurosci 8:3827-3837.

Colmers WF, Klapstein GJ, Fournier A, St-Pierre S, Treherne KA (1991) Presynaptic inhibition by ncuropeptide $\mathrm{Y}$ in rat hippocampal slice in vitro is mediated by a $Y_{2}$ receptor. $\mathrm{Br} \mathrm{J}$ Pharmacol 102:41-44. 
Corp ES, Smith GP (1991) Characterization of axonally transported [125]PYY binding sites in rat vagus nerve. Brain Res 553:175-179.

Danho W, Triscari J, Vincent G, Nakajima T, Taylor J, Kaiser ET (1988) Synthesis and biological evaluation of pNPY fragments. Int J Pept Prot Res 32:496-505.

DeQuidt ME, Emson PC (1986a) Distribution of neuropeptide Y-like immunoreactivity in the rat central nervous system: I. Radioimmunoassay and chromatographic characterisation. Neuroscience 18:527543.

DeQuidt ME, Emson PC (1986b) Distribution of neuropeptide Y-like immunoreactivity in the rat central nervous system: II. Immunohistochemical analysis. Neuroscience 18:545-618.

Dumont Y, Fournier A, St-Pierre S, Schwartz TW, Quirion R (1990) Differential distribution of neuropeptide $Y 1$ and $Y 2$ receptors in the rat brain. Eur J Pharmacol 191:501-503.

Dumont Y, Martel JC, Fournier A, St-Pierre S, Quirion R (1992) Neuropeptide $Y$ and Neuropeptide $Y$ receptor sub-types in brain and peripheral tissues. Prog Neurobiol 38:125-167.

Emson PC, DeQuidt ME (1984) NPY a new member of the pancreatic polypeptide family. Trends Neurosci 7:31-34.

Eva C, Keinanen K, Monyer H, Seeburg P, Sprengel R (1990) Molecular cloning of a novel $\mathrm{G}$ protein-coupled receptor that may belong to the neuropeptide receptor family. FEBS Lett 271:81-84.

Flood JF, Morley JE (1989) Dissociation of the effects of neuropeptide $Y$ on feeding and memory: evidence for pre- and postsynaptic mediation. Peptides 10:963-966.

Forest M, Martel JC, St-Pierre S, Quirion R, Fournier A (1990) Structural study of the $\mathrm{N}$-terminal segment of neuropeptide tyrosine. J Med Chem 33:1615-1619.

Fuhlendorff J, Gether U, Aakerlund L, Langeland-Johansen N, Thogersen H, Melberg SG, Olsen UB, Thastrup O, Schwartz TW (1990a) $\left[\mathrm{Leu}^{31}, \mathrm{Pro}^{34}\right]$ neuropeptide $\mathrm{Y}$ : a specific $\mathrm{Y}_{\text {, receptor agonist. Proc Natl }}$ Acad Sci USA 87:182-186.

Fuhlendorff J, Langeland-Johansen N, Melberg SG, Thogersen H, Schwartz TW (1990b) The antiparallel pancreatic polypeptide fold in the binding of neuropeptide $Y$ to $Y_{1}$ and $Y_{2}$ receptors. J Biol Chem 265:11706-11712.

Grundemar L, Wahlestedt C, Reis DJ (1991) Neuropeptide Y acts at an atypical receptor to evoke cardiovascular depression and to inhibit glutamate responsivencss in the brainstem. J Pharmacol Exp Ther 258:633-638.

Härfstrand A, Fredholm B, Fuxe K (1987) Inhibitory effects of neuropeptide $Y$ on cyclic AMP accumulation in slices of the nucleus tractus solitarius region of the rat. Neurosci Lett 76:185-190.

Heilig M, Murison R (1987) Intracerebroventricular neuropeptide $Y$ (NPY) suppresses home cage and open field activity in the rat. Regul Pept 19:221-231.

Heilig M, Wahlestedt C, Widerlöv E (1988) Neuropeptide Y (NPY)induced suppression of activity in the rat: evidence of NPY receptor heterogeneity and for interaction with $\alpha$-adrenoceptors. Eur J Pharmacol 157:205-213.

Herzog H, Hort YJ, Ball HJ, Hayes G, Shine J, Selbie LA (1992) Cloned human neuropeptide $Y$ receptor couples to two different second messenger systems. Proc Natl Acad Sci USA 89:5794-5798.

Hinson J, Rauh C, Coupet J (1988) Neuropeptide Y stimulates inositol phospholipid hydrolysis in the rat brain miniprisms. Brain Res 446 : 379-382.

Inui A, Oya M, Okita M, Inoue T, Sakatani N, Morioka H, Shii K, Yokono K, Mizuno N, Baba S (1988) Peptide YY receptors in the brain. Biochem Biophys Res Commun 150:25-32.

Inui A, Okita M, Inoue T, Sakatani N, Oya M, Morioka H, Shii K, Yokono K, Mizuno N, Baba S (1989) Characterization of peptide $Y Y$ receptors in the brain. Endocrinology 124:402-409.

Jolicoeur FB, Michaud JN, Rivest R, Menard D, Gaudin D, Fournier A, St-Pierre S (1991a) Neurobehavioral profile of neuropeptide Y. Brain Res Bull 26:265-268.

Jolicoeur FB, Michaud JN, Menard D, Fournier A, St-Pierre S (1991b) In vivo structure activity study supports the cxistencc of heterogeneous neuropeptide Y receptors. Brain Res Bull 26:309-311.

Kalra SP, Clark JT, Sahu A, Dube MG, Kalra PS (1988) Control of feeding and sexual behaviors by neuropeptide $\mathrm{Y}$ : physiological implications. Synapse 2:254-257.

Kalra SP, Sahu A, Kalra PS, Crowley WR (1990) Hypothalamic neuropeptide $\mathrm{Y}$ : a circuit in the regulation of gonadotropin secretion and feeding behavior. Ann NY Acad Sci 611:273-283.
Leibowitz SF, Alexander JT (1991) Analysis of neuropeptide Y-induced feeding: dissociation of $Y_{1}$ and $Y_{2}$ receptor effects on natural meal patterns. Peptides 12:1251-1260.

Lynch DR, Walker MW, Miller RJ, Snyder SH (1989) Neuropeptide $Y$ receptor binding sites in rat brain: differential localization with [ $\left.{ }^{125} \mathrm{I}\right]$ peptide $\mathrm{YY}$ and $\left[{ }^{125} \mathrm{I}\right]$ neuropeptide $\mathrm{Y}$ imply receptor heterogeneity. J Neurosci 9:2607-2619.

Magdalin W, Stanley BG, Fournier A, Leibowitz A (1989) Structureactivity analysis of neuropcptide $\mathrm{Y}$-induced eating behavior. Soc Neurosci Abstr 15:895.

Martel JC, St-Pierre S, Quirion R (1986) Neuropeptide Y receptors in rat brain: autoradiographic localization. Peptides 7:55-60.

Martel JC, St-Pierre S, Bédard PJ, Quirion R (1987) Comparison of [125] Bolton-Hunter neuropeptide $Y$ binding sites in the forebrain of various mammalian species. Brain Res 419:403-407.

Martel JC, St-Pierre S, Quirion R (1988) Comparative distribution of neuropeptide $Y$ immunoreactivity and receptor autoradiography in rat forebrain. Peptides 9:15-20.

Martel JC, Fournier A, St-Pierre S, Quirion R (1990a) Quantitative autoradingraphic distribution of [125I]Bolton-Hunter neuropeptide $Y$ receptor binding sites in rat brain. Comparison with [ $\left.{ }^{125} \mathrm{I}\right]$ peptide $Y Y$ receptor sites. Neuroscience 36:255-283.

Martel JC, Fournier $\Lambda$, St-Pierre S, Dumont Y, Forest M, Quirion R (1990b) Comparative structural requirements of brain neuropeptide $Y$ binding sites and vas deferens neuropeptide $Y$ receptors. Mol PharInacol 38:494-502.

McGregor IS, Menendez JA, Atrens DM (1990) Metabolic effects of neuropeptide $\mathrm{Y}$ injected into the sulcal prefrontal cortex. Brain Res Bull 24:363-367.

Monnet FP, Debonnel G, Fournier A, de Montigny C (1992) Potentiation by high affinity sigma ligands and by neuropeptide $\mathrm{Y}$ of $N$. methyl-D-aspartate-induced neuronal activation: in vivo electrophysiological studies on rat dorsal CA3 hippocampus pyramidal neurons. In: Multiple sigma and PCP receptor ligands: mechanisms for neuromodulation and neuroprotection? (Kamenka JM, Domino EF, eds), pp 493-505. Ann Arbor, MI: NPP Books.

O'Donohue TL, Chronwall BM, Pruss RM, Mezcy E, Kiss JZ, Eiden LE, Massari VJ, Tessel RE, Pickel VM, DiMaggio DA, Hotchkiss AJ, Crowley WR, Zukowska-Grojec Z (1985) Neuropeptide $Y$ and peptide YY neuronal and endocrine systems. Peptides 6:755-768.

Ohkubo T, Niwa M, Yamashita K, Kataoka Y, Shigematsu K (1990) Neuropeptide $Y$ (NPY) and peptide YY (PYY) receptors in rat brain. Cell Mol Neurobiol 10:539-552.

Petrenko S, Olianas MC, Onali P, Gessa GL (1987) Neuropeptide Y inhibits forskolin-stimulated adenylate cyclase activity in rat hippocampus. Eur J Pharmacol 136:425-428.

Quirion R, Martel JC, Dumont Y, Cadieux A, Jolicoeur F, St-Pierre S, Fournier A (1990) Neuropeptide $Y$ receptors: autoradiographic distribution in brain and structure-activity relationships. Ann NY Acad Sci 611:58-72.

Quirion R, Martel JC (1992) Brain neuropeptide Y receptors: distribution and possible relevance to function. In: Handbook of chemical neuroanatomy, vol 11 (Bjorklund A, Hökfelt TH, Kuhar MJ, eds), pp 247-287. Amsterdam: Elsevier.

Rimland J, Sin W, Sweetnam P, Saijoh K, Nestler EJ, Duman DS (1991) Sequence and expression of a neuropeptide $Y$ receptor $c D N A$. Mol Pharmacol 40:869-875.

Roman FJ, Pascaud X, Duffy O, Vauche D, Martin B, Junien JL (1989) Neuropeptide $Y$ and peptide $Y Y$ interact with rat brain $\Sigma$ and PCP binding sites. Eur J Pharmacol 174:301-302.

Rosier AM, Orban GA, Vandesande F (1990) Regional distribution of binding sites for neuropeptide $\mathrm{Y}$ in cat and monkey visual cortex determined by in vitro receptor autoradiography. J Comp Neurol 293: $486-498$.

Saria A, Theodorsson-Norheim E, Lundberg JM (1985) Evidence for specific neuropeptide $Y$-binding sites in rat brain synaptosomes. Eur J Pharmacol 107:105-107.

Schwartz TW, Fuhlendorff J, Kjerns LL, Kristensen MS, Vervelde M, O'Hare M, Krstenansky JL, Bjornholm B (1990) Signal epitopes in the three-dimensional structure of neuropeptide $Y$ : interaction with $Y_{1}, Y_{2}$ and pancreatic polypeptide receptors. Ann NY Acad Sci 61I: $35-47$.

Sheikh SP, Håkanson R, Schwartz TW (1989a) Y1 and Y2 receptors for neuropeptide Y. FEBS Lett 245:209-214.

Sheikh SP, O'Hare MMT, Tortora O, Schwartz TW (1989b) Binding 
of monoiodinated neuropeptide $Y$ to hippocampal membranes and human neuroblastoma cell lines. J Biol Chem 264:6648-6654.

Sheikh SP, Williams JA (1990) Structural characterization of $Y_{1}$ and $Y_{2}$ receptors for neuropeptide $Y$ and pcptide $Y Y$ by affinity cross-linking. J Biol Chem 265:8304-8310.

Stanley BG, Leibowitz SF (1984) Neuropeptide Y: stimulation of feeding and drinking by injection into the paraventricular nucleus. Life Sci 35:2635-2642.

Stanley BG, Daniel DR, Chin AS, LeibowitzSF (1985) Paraventricular nucleus injections of peptide YY and neuropeptide $Y$ preferentially enhance carbohydrate ingestion. Peptides 6:1205-1211.

Tatemoto K (1982) Neuropeptide Y: complete amino acid sequence of the brain peptide. Proc Natl Acad Sci USA 79:5485-5489.

Tatemoto K, Carlquist M, Mutt V (1982) Neuropeptide Y: a novel brain peptide with structural similarities to peptide $Y Y$ and pancreatic polypeptide. Nature 296:659-660.

Terenghi G, Polak JM, Hamid Q, O'Brien E, Denny P, Legon S, Dixon J, Minth CD, Palay SL, Yarsagil G, Chan-Palay V (1987) Localization of neuropeptide Y mRNA in neurons of human cerebral cortex by means of in situ hybridization with a complementary RNA probe. Proc Natl Acad Sci USA 84:7315-7318.

Wahlestedt C, Yanaihara N, Håkanson R (1986) Evidence for different pre- and post-junctional receptors for neuropeptide $Y$ and related peptide. Regul Pept 13:307-318.

Wahlestedt C, Regunathan S, Reis DJ (1992) Identification of cultured cells selectively expressing Y1-, Y2-, or Y3-type receptors for neuropeptide Y/peptide YY. Life Sci 50:PL7-PL12.
Walker MW, Miller RJ (1988) ${ }^{125}$ I-neuropeptide $Y$ and ${ }^{125}$ I-peptide YY bind to multiple receptor sites in rat brain. Mol Pharmacol 34: 779-792.

Walker MW, Ewald DA, Perney TM, Miller RJ (1988) Neuropeptide $Y$ modulates neurotransmitter release and $\mathrm{Ca}^{2+}$ currents in rat sensory neurons. J Neurosci 8:2438-2446.

Westlind-Danielsson A, Undên A, Abens J, Andell S, Bartfai T (1987) Neuropeptide $Y$ receptors and the inhibition of adenylate cyclase in the human frontal and temporal cortex. Neurosci Lett 74:237-242.

Westlind-Danielsson A, Andell J, Abens J, Bartfai T (1988) Neuropeptide $\mathrm{Y}$ and peptide $\mathrm{YY}$ inhibit adenylate cyclase activity in the rat striatum. Acta Physiol Scand 132:425-430.

Widdowson PS, Halaris AE (1990a) Effects of neuropeptide $Y$ on alpha 1 - and beta-adrenoceptor-stimulated second messenger systems in rat frontal cortex. Peptides 11:661-665.

Widdowson PS, Halaris AE (1990b) A comparison of the binding of $\left[{ }^{3} \mathrm{H}\right]$ proprionyl-neuropeptide $\mathrm{Y}$ to rat and human frontal cortical membranes. J Neurochem 55:956-962.

Whitcomb DC, Taylor IL, Vigna SR (1990) Characterization of saturable binding sites for circulating pancreatic polypeptide in rat brain. Am J Physiol 259:G687-G691.

Yee F, Larhammar D, Blomqvist A, Jazin E, Yoo H, Reis DJ, Wahlested $C$ (1992) Molecular cloning and characterization of a Yl-receptor recognizing neuropeptide $Y$ (NPY) and peptide YY (PYY). In: XIIth Washington International Spring Symposium, Abstract 149. New York: Plenum. 